\title{
Morfología macroscópica de alteración de la piedra de la catedral de Guadíx/España
}

\author{
Macroscopical morphology of deterioration \\ of the stone in the cathedral of Guadix/Spain
}

\author{
M. ALCALDE, Dr. Ing. Industrial. Dto. de Ingeniería Química y Ambiental. \\ A. MARTIN, Dr. en Ciencias Químicas y Geológicas. Dto. de Química Analítica. \\ UNIVERSIDAD DE SEVILLA/ESPANAA
}

Fecha de recepción: 25-XI-91

RESUMEN

Los principales factores de alteración que afectan a la catedral de Guadix son de origen natural,

fundamentalmente térmico $\theta$ hidráulico, por sus grandes oscilaciones de temperatura en verano y por la frecuencia de heladas en invierno, y por la lluvias. Los litotipos empleados son principalmente calcarenitas de porosidad media y calizas algo más compactas, procedentes de canteras de la zona, y mármoles. Los mecanismos de alteración correspondientes son los de dilatación térmica diferencial originados por los saltos térmicos, en especial en las piedras más compactas, los de incremento de volumen en capilares e intersticios, sobre todo por heladicidad, y los de disolución. Los indicadores de alteración más graves son las fisuras y fragmentaciones que afectan a los elementos más labrados y que han llevado al estado de ruina a la mayor parte de los elementos más aireados como los pináculos.

\section{$S U M M A R Y$}

The main factors of deterioration that affect the Cathedral of Guadix are of a natural origin, basically thermic and hidraulic, due to its great oscillations in temperature in Summer, the frecuency of frosts in Winter and the rains. The lithotypes employed are mainly calcarenite of mean porosite and slightly more compact limestones from the quarries in the area, and marbles. The corresponding deterioration mecanisms are those of diferential thermic dilatations caused by thermic jumps, especially in the more compact stones, those of increase in volume in capillaries and interstices, especially by freezing, and those of dissolution. The most serious deterioration indicators are fissures and spalling that affect the most carved elements and which have taken the greater part of the most aerated elements such as the pinnacles to a state fo ruin.

\section{INTRODUंCCIÓN}

La construcción de la catedral de Guadix, cuya institución a finales del XV fue simutánea a las de Granada, Almería y Málaga, sufrió un proceso muy complejo por problemas económicos y de entendimiento entre sus responsables que hace que éste se extienda durante los siglos $\mathrm{XVI}$ al $X V I I I$, con algunas intervenciones en el XIX. Aunque se comienza con elementos góticos, en la parte que hoy es el coro, y posiblemente sobre la Mezquita Mayor, Siloé sustituye a finales del XVI la anterior fábrica, dando un nuevo carácter renacentista a la catedral. El aporte barroco de Acero y Cayón en el XVIII se hace patente, sobre todo, en las portadas. El resultado es un templo de tres naves, planta gótica de salón con una gran girola y numerosas capillas laterales, y una magnífica cúpula sobre el crucero, que hacen de

\section{INTRODUCTION}

The construction of the Cathedral of Guadix, whose institution at the end of 15th century was simultaneous to those of Granada, Almería and Málaga, underwent a very complex process due to economic problems and understanding among the people responsables which prolonged this into 16 th to 18th centuries and with some interventions even in 19th century. Although it was started with gothic elements in the parts which are now the choir-loft, and possibly on the Main Mosque, Siloe substituted the previous masonry at the end of 16th century so giving a new Renaissancist character to the Cathedral. The Barroque contribution by Acero and Cayon is best seen, above all, in the portals. The result is a three-nave temple, a Gothic floor incluiding a hall with a great apse aisle with numerous lateral chapels, and a 
este monumento uno de los más interesantes de Andalucía Oriental.

Como incidencias hay que señalar las múltiples interrupciones de obras, entre las cuáles cabe destacar la de 1574, con el ábside, la capilla de San Torcuato y la portada de la sacristía levantadas hasta las cornisas y sin cubrir aguas. En el 1594 se reanudan con otro estilo, de concepción más vertical, comenzándose una gran torre, objeto de muchas controversias, en que se cambia la piedra por el ladrillo, más barato. En el 1608 se vuelven a interrumpir las obras y a finales del XVII se vuelve a la concepción horizontal. El fin de obras se puede localizar en el 1799 , tras un proceso de 250 años.

\section{ENTORNO AMBIENTAL}

La catedral de Guadix está ubicada en el casco urbano, en un lugar alto bien barrido por los vientos. La orientación longitudinal del templo es del Noroeste al Sureste, siendo su fachada principal la situada al Sureste. Está flanqueada por calles estrechas al SE y al SO, con poca circulación de vehículos, y prácticamente adosada a la residencia episcopal por el lado NO. La fachada NE da a un gran espacio abierto con un paseo peatonal, teniendo adosadas la iglesia del Sagrario y la sala capitular en el flanco oriental y la torre y la sacristía en el occidental.

\subsection{Clima}

Guadix pertenece a la región climática mediterránea continental extremada, meseta Sur. Está enclavada en un surco intrabético denominado la Hoya de Guadix, a considerable altitud (unos $1.000 \mathrm{~m}$ sobre el nivel del mar), en la caída septentrional de Sierra Nevada, lo que dificulta la influencia del Mediterráneo, provocando un clima riguroso de inviernos largos y muy fríos con frecuentes heladas, y veranos cortos calurosos con oscilaciones amplias de temperatura entre el día y la noche. Las lluvias se concentran en primavera y en otoño son de origen tormentoso.

De los datos contenidos en el Atlas Climático de España, con valores correspondientes a 30 años, se pueden extraer las siguientes conclusiones más importantes:

Julio es el mes más cálido, con una media en sus temperaturas máximas diarias de $34^{\circ} \mathrm{C}$. La influencia de las heladas puede ser considerable ya que la media anual de días en que la temperatura mínima desciende por debajo de $0^{\circ} \mathrm{C}$ es de 40. Los meses más fríos son diciembre, enero y febrero, con una media de sus temperaturas mínimas diarias de $1^{\circ} \mathrm{C}$. Las magnificent dome above transept, which make this monument one of the most interesting monuments in Eastern Andalusia.

As incidents, we have to point out the multiple in works amongst which the one in 1574 stands out when the apsis, the San Torcuato chapel and the sacristy portal were raised up to the cornices without topping out. In 1594 work was reasumed in another style, having a more vertical conception, starting with a great tower which was an object of many controversies. The stone was changed for cheaper bricks. In 1608, work was interrupted once more and at the end of 17th century they returned to the horizontal conception. The end of the works can be located in 1799 after a process of 250 years.

\section{ENVIRONENTAL SURROUNDINGS}

The Cathedral of Guadix is located within the city on high ground, well swept by winds. The longitudinal orientation of the Temple is from the North West to South East with its main façade being located to the South East. It is flanked by narrow streets to the $S E$ and $S W$ with very little traffic, and practically joined to the episcopal residence on the NW side. The NE façade faces a great open space with a pedestrian walk, having the Sagrarium Church and Capitulary Hall joined to its Eastern flank and the tower and sacristry on its Western wing.

\subsection{Climate}

Guadix belongs to the extreme continental Mediterranean climatical region, Southern plateau. It is enclaved in an interandalusian forrow called "La Hoya de Guadix" at a considerable height (some 1.000 metres above sea level) on the Northern descent of Sierra Nevada, which makes Mediterranean influence difficult, so provoking a severe climate with long, cold Winters with frequent frosts and short, hot Summers with wide oscillations of temperature between day and night. The rains are concentrated in Spring and Autumn, usually being stormy.

From data, corresponding to 30 years, contained in the Climatical Atlas of Spain we can draw the following more important conclusions:

July is the hottest month, having an average daily maximum temperature of $34^{\circ} \mathrm{C}$. The influence of frosts can be considerable as the yearly average of days when the minimum temperature is below zero is 40 . The coldest months are December, January and February whose average daily minimum is $1^{\circ} \mathrm{C}$. The daily oscillations in temperature (maximum-minimum) has a yearly 
oscilaciones diarias de temperatura (máximamínima) tienen una media anual de $14^{\circ} \mathrm{C}$, siendo máximas en junio, julio y agosto con 17,18 y $19^{\circ} \mathrm{C}$ respectivamente.

La humedad relativa presenta valores máximos a primeras horas de la mañana y mínimos al mediodía. Una imagen de las oscilaciones que ésta presenta se tiene comparando los valores medios a las $7 \mathrm{~h}$ y $13 \mathrm{~h}$ en los meses de julio (60\% y $30 \%$ respectivamente) y enero (90\% y $65 \%)$.

La precipitación media anual es de $300 \mathrm{l} / \mathrm{m}^{2}$. Abril y mayo son los meses de mayor media pluviométrica, con 50 y $40 \mathrm{l} / \mathrm{m}^{2}$ respectivamente y julio y agosto los de menor, con menos de $5 \mathrm{l} / \mathrm{m}^{2}$. La precipitación máxima en 24 h es de unos $150 \mathrm{l} / \mathrm{m}^{2}$.

Los vientos dominantes a lo largo del año son del $S$ y SO. La velocidad media anual es de $10 \mathrm{~km} / \mathrm{h}$ superándose la velocidad de $50 \mathrm{~km} / \mathrm{h}$ sólo algunos días del verano.

\subsection{Contaminación}

No se dispone de datos de contaminación. No obstante, dado que la catedral no se encuentra protegida de los vientos por edificios altos y que, por las características urbanísticas la circulación rodada en la zona es escasa, no cabe esperar que los valores de inmisión de contaminantes de origen antropogénico sean significativos. La principal actividad de Guadix es comercial, agrícola y ganadera, con algunas industrias artesanales sin actividad contaminadora de consideración.

\section{MATERIALES PÉTREOS}

La bibliografía que maneja los documentos de los archivos catedralicios menciona una serie de canteras que aparecen en los mismos como suministradores de la piedra con que se construyó la catedral de Guadix. Así se habla de que en 1598 se traen piedras de Almidar para la cúpula de la capilla actualmente de San Torcuato y en 1629 para cerrar el crucero mayor, en 1714 de Lapeza y de la Sierra de Baza, a las que se unen Bogarre en 1720, Bácor y Bérchules en 1731 y Gor y Gorafe en 1763; también se menciona Escúzar. Todas ellas parece ser que con fines fundamentalmente estructurales; de Gorafe se sabe que proceden las utilizadas en 1791 en las cuatro agujas de los ángulos del cubo cuadrado de la torre. Como piedras especiales de carácter ornamental se mencionan el mármol de Macael para los medallones, jaspe de Sierra Elvira para las gradas de los púlpitos, jaspe de Diezma, losas del Raposo, etc. average of $14^{\circ} \mathrm{C}$. June, July and August have the maximum at 17,18 and $19^{\circ} \mathrm{C}$ respectively.

The relative humidity gives a maximum in the early hours of the morning and a minimum at midday. An idea of the oscillations this shows can be seen by comparing average values at 7 and $13 \mathrm{~h}$ in July (60\% and $30 \%$ respectively) and January (95\% and $65 \%$ ).

The average yearly rainfall is $300 \mathrm{l} / \mathrm{m}^{2}$. April and May are the months with higher pluviometry, 50 and $40 \mathrm{l} / \mathrm{m}^{2}$ respectively, while July and August have less than $5 \mathrm{l} / \mathrm{m}^{2}$. The maximum rainfall in 24 hours is about $150 \mathrm{l} / \mathrm{m}^{2}$.

The dominating winds during the year are Southern and South Western. The average yearly speed is $10 \mathrm{~km} / \mathrm{h}$ surpassing $50 \mathrm{~km} / \mathrm{h}$ on some Summer days.

\subsection{Pollution}

Data on contamination is not available. Nevertheless, as the Cathedral is not protected from the winds by high buildings and since the lack of traffic due to urban characteristics we do not think the values of immission of contaminants of anthropogenical origin are significant. The main activities of Guadix are commerce, agriculture and livestock, and some craftsmen industries without having contaminating activity of consideration.

\section{PETROUS MATERIALS}

The bibliography on the documents of the Cathedral Archives mentions a series of quarries which appear as suppliers of stone which the Cathedral of Guadix was built with. So they say that in 1598 stone was brought from Almidar for the dome of the chapel now known as San Torcuato and, in 1629, to finish the main crossbearer. In 1714, stone was brought from Lapeza and Sierra de Baza in 1720 from Bogarre, in 1731 from Bácor and Bérchules and in 1763 from Gor and Gorafe; Escúzar is also mentioned. All these seem to be used basically for structural ends. It is known that the ones from Gorafe were used for the four spires of the corners of squeare die of the tower in 1791. Marble from Macael in the medallions; jasper from Sierra Elvira for the pulpit steps, jasper from Diexma, tiles from Raposo, etc. are mentioned as special stones for ornamental use. 
De los análisis realizados a muestras de elementos fragmentados de las zonas altas del edificio, se ha encontrado que la mayor parte de ellas poseen una gran homogeneidad en su composición química y propiedades físicas, y muy similares a las obtenidas en muestras extraidas de las canteras de Bácor. La cantera de Escúzar parece ser la suministradora de las calizas de ciertas partes del edificio, identificables por su color blanco, aunque no se ha analizado un suficiente número de muestras representativo.

En la Tabla 1 se dan los rangos de valores obtenidos en la composición química (componentes mayoritarios), así como los de densidad, porosidad y agua de saturación, en las muestras de la catedral y de las canteras de Bácor, de Lapeza y de Escúzar.

Otros materiales que se mencionan son las típicas arcillas accitanas para las esculturas, yeso para ciertas molduras y ladrillos para la torre. Las cornisas están protegidas con aleros de pizarra.
We have found from the analysis carried out on samples taken from different fragmented elements in the higher zones of the building, that the majority possess a great homogeneity in their chemical composition and physical properties, very similar to those obtained in samples from de Bácor quarries. The Escúzar quarry seems to be the supplier of the white limestones of the same parts of the building, although the number of analyzed samples is not sufficiently representative.

In Table 1 the ranges in values obtained in the chemical composition (majority components) as well as the density, porosity and water saturation of the samples from the Cathedral and Bácor, Lapeza and Escúzar quarries are given.

Other materials that are mentioned are the typical accitana clays used in sculpture, gypsum for certain moldings and bricks for the tower.

Cornices are protected by slate shale eaves.

TABLA 1 TABLE 1

Composición química y propiedades físicas en muestras de la catedral y en canteras de Bácor, Lapeza y Escúzar

Chemical Coomposition and Physical Properties of samples from the Cathedral and from Bácor, Lapeza and Escúzar quarries

\begin{tabular}{|c|c|c|c|c|}
\hline & $\begin{array}{l}\text { MUESTRAS } \\
\text { CATEDRAL } \\
\text { (CATHEDRAL } \\
\text { SAMPLES) }\end{array}$ & $\begin{array}{l}\text { CANTERA } \\
\text { DE BÁCOR } \\
\text { (BACOR } \\
\text { QUARRY) }\end{array}$ & $\begin{array}{c}\text { CANTERA } \\
\text { DE LAPEZA } \\
\text { (LAPEZA } \\
\text { QUARRY) }\end{array}$ & $\begin{array}{l}\text { CANTERA } \\
\text { DE ESCÚZAR } \\
\text { (ESCUZAR } \\
\text { QUARRY) }\end{array}$ \\
\hline $\begin{array}{l}\text { Pérdida calcinación } \\
\text { (Calcin. lost) }\end{array}$ & $35,1-35,5$ & $36,7-37,4$ & $24,6-26,0$ & 42,9 \\
\hline $\mathrm{SiO}_{2}$ & $16,8-17,1$ & $13,2-14,3$ & $37,5-40,3$ & 1,50 \\
\hline $\mathrm{CaO}$ & $41,1-41,9$ & $43,0-43,5$ & $27,3-29,7$ & 53,0 \\
\hline $\mathrm{Al}_{2} \mathrm{O}_{3}$ & $1,26-1,80$ & $1,30-1,52$ & $2,38-2,81$ & 0,38 \\
\hline $\mathrm{Fe}_{2} \mathrm{O}_{3}$ & $1,02-1,14$ & $0,85-0,95$ & $1,10-1,37$ & 0,24 \\
\hline $\mathrm{MgO}$ & $2,06-2,26$ & $2,06-2,36$ & $2,08-2,91$ & 0,41 \\
\hline $\mathrm{Na}_{2} \mathrm{O}$ & $0,83-1,06$ & $0,88-1,04$ & $0,58-0,69$ & - \\
\hline $\mathrm{K}_{2} \mathrm{O}$ & $0,58-0,65$ & $0,55-0,65$ & $0,62-0,67$ & - \\
\hline $\mathrm{SO}_{3}$ & $0,30-0,40$ & $0,34-0,36$ & $0,21-0,30$ & - \\
\hline $\begin{array}{l}\text { Densidad kg/l } \\
\text { (Density kg/) }\end{array}$ & 2,07 & 2,06 & $1,94-2,03$ & 1,84 \\
\hline $\begin{array}{l}\text { Porosidad \% } \\
\text { (Porosity \%) }\end{array}$ & 20,71 & 20,79 & $23,1-25,4$ & 29,66 \\
\hline $\begin{array}{l}\text { Saturación \% } \\
\text { (Saturation \%) }\end{array}$ & 9,99 & 10,07 & $11,6-13,1$ & 16,15 \\
\hline
\end{tabular}




\section{MORFOLOGÍA MACROSCÓPICA DE LAS ALTERACIONES}

Se hará una descripción por fachadas, comenzando por la principal, orientada al Sudeste. Dentro de cada fachada, tras unas consideraciones previas acerca de los materiales de construcción empleados, clima, urbanismo, ambiente y agentes biológicos, lo que puede orientar acerca de los factores de alteración que pueden intervenir, se hace una descripción de los indicadores visuales de alteración, siguiendo un criterio en el cual se estudian ordenadamente las modificaciones superficiales, deformaciones, disyunciones, eliminaciones de materia y rupturas, empleando para ello los términos sistematizados por los autores (Martín, 1990).

\subsection{Fachada principal}

La piedra que fundamentalmente se ha empleado en la construcción de esta fachada es una calcarenita de color amarillo, con algunas diferencias de tonalidad entre unos sillares y otros (Fig. 1a). El basamento (Fig. 2f), la escultura de mármol que hay en el segundo cuerpo, dedicada a la Anunciación y que da nombre a esta portada (Fig. 1b), el escudo del segundo cuerpo y la lápida del remate, son de mármol de Macael. Las cornisas se protegieron con losas de pizarra que, en general, están en mal estado (Fig. 1d y 2d). El remate por el lado interior está protegido por un muro de ladrillo y cemento. Se observan numerosas aplicaciones de morteros en labores de mantenimiento anteriores (Fig. 2b), así como en las restauraciones que en el momento de hacer el presente estudio se están llevando a cabo (Fig. 1a).

Dada la orientación al Sudeste, esta fachada está soleada en la primera mitad del día y recibe los vientos dominantes del Sur. Los edificios cercanos no le proyectan sombra pero apantallan de los vientos las zonas inferiores a la izquierda. La precede una espaciosa entrada con una calle estrecha de poco tráfico, por lo que no se prevé una alta contaminación atmosférica.

Como agentes biológicos sólo merecen mencionarse los líquenes, cuyo mayor desarrollo se da en las zonas más altas, como son los pináculos, bolas y antepechos (Fig. 2b). Estas colonias son más abundantes en las superficies orientadas al Norte donde, a veces, se forman almohadillados de musgo.

Como modificaciones superficiales se pueden señalar, en primer lugar, la pátina propia del paso del tiempo que afecta de forma general a toda la superficie oscureciendo la tonalidad de la piedra y endureciéndola (Fig. 1a y b). En los mármoles de las basas se aprecian fuertes tonalidades ocres, probablemente tinciones producidas por algún

\section{MACROSCOPICAL MORPHOLOGY OF THE DETERIORATIONS}

A description by façade will be given starting with the main one facing South East. Within each façade, afther previous considerations on the materials used in construction, climate, urbanism, enviroment and biological agents, what can orientate about the factors of deterioration that intervene, a description of the visual indicators of deteriorations is made following a methodical criteria in which the superficial modifications, deformatins, disjunctions, eliminations of material and ruptures using the systematized terms by the authors (Martin 1990) are studied.

\subsection{Main Façade}

The stone basically used in the construction of this façade is a yelow calcarenite with some differences in tone between some ashlars and others (Fig. 1a). The basement (Fig. 2f), the marble sculpture on the second body dedicated to the Annunciation-day and which gives its name to the portal (Fig. 1b) the shield of the second body and the memorial stone are marble from Macael. The cornices are protected by slate tiles which, in general, are in a bad state (fig. 1d and 2d). The crest on the inside is protected by a brick and cement wall. Numerous applications of mortar are observed in labours of previous maintenance (Fig. 2b) as well as in the restorations which are being carried out at time of this study (Fig. 1a).

Given its orientation to SE this façade is sunbacked during the first half of the day and receives the dominating Southern winds. The neighbouring edifications do not project shade but screen the lower areas to the left from the wind. It faces a spacious entrance with a narrow street with little traffic so high atmospherical contamination is not foreseeen.

Only lichens can be mentioned as biological agents whose greater development is found in the higher areas such as the pinnacles, globes and breastwork (Fig. 2b). These colonies are more abundant on surfaces facing North where the moss sometimes forms bossages.

Patina due to the pass of time can be shown as a main superficial modification which generally affect all the surface by making the tonality of stone darker and hardening it (Fig. 1a and b). In the marbles of the basements strong ocres tonalities are appreciated probably stains produced by some old treatment (fig. 2f). Stains 


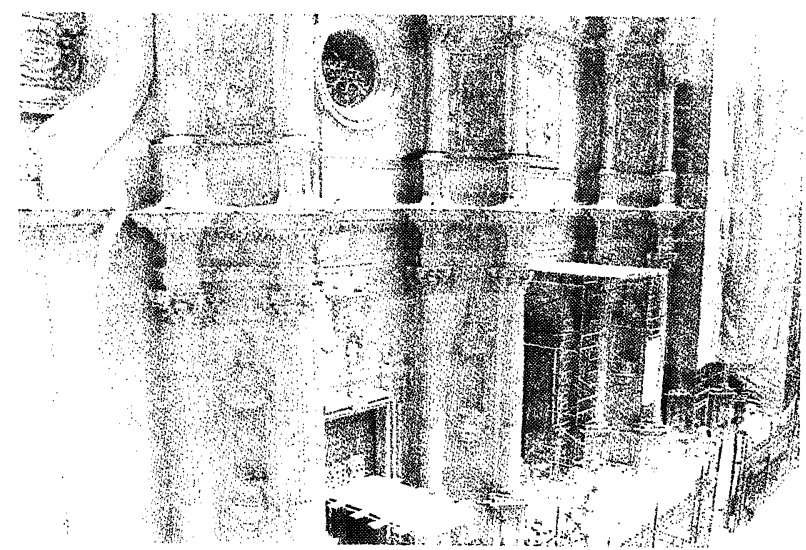

a) Vista general de la fachada.

a) General view of the façade.

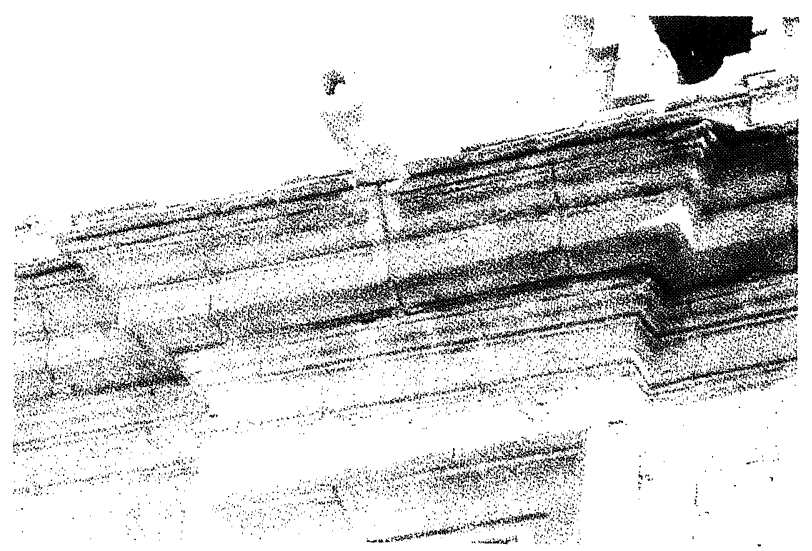

c) Depósitos debajo de las cornisas.

c) Deposits under the cornices.

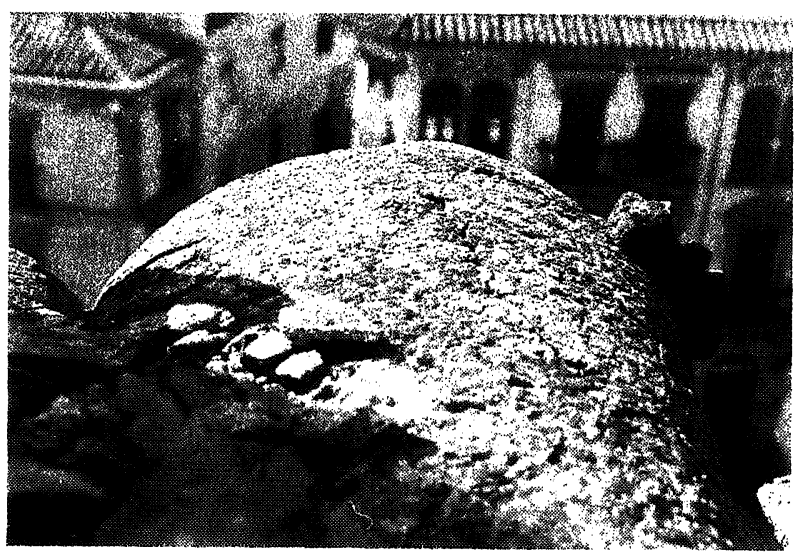

e) Disyunciones de placas.

e) Contour scaling.

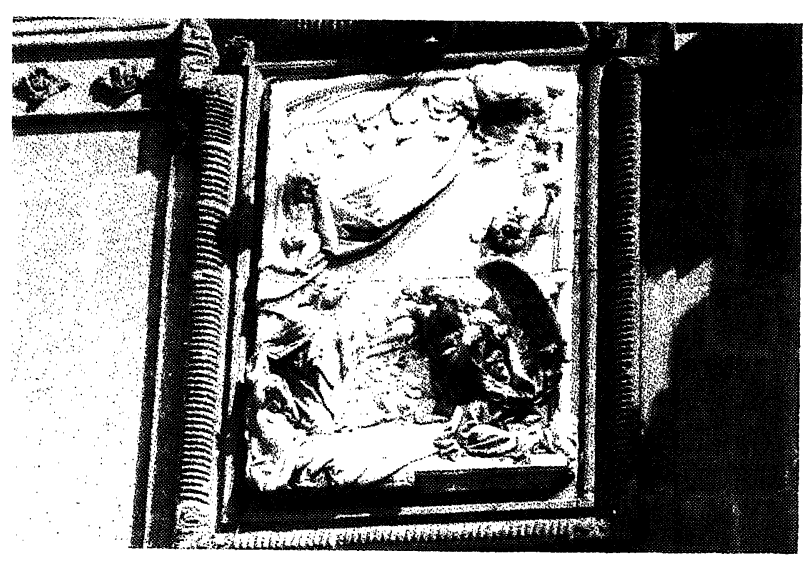

b) Depósitos de polvo en los pliegues de las esculturas

b) Deposits of dust in the folds of the sculptures.

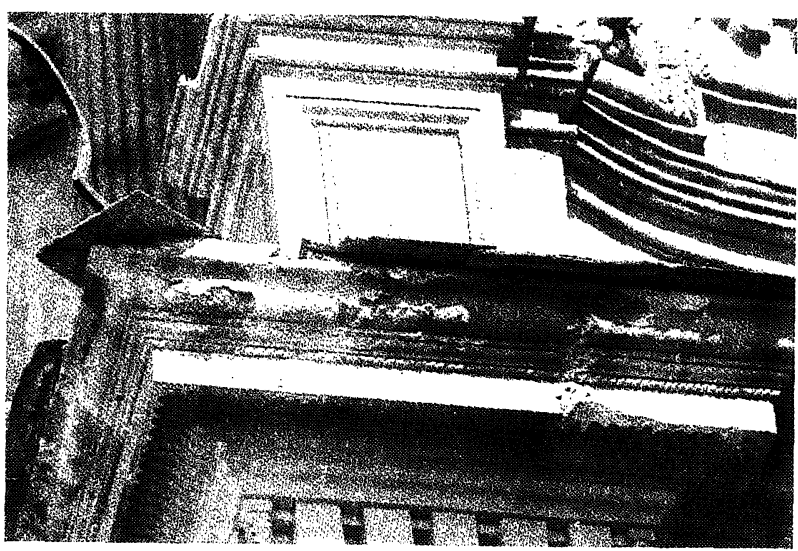

d) Disyunciones de películas y disgregaciones en las cornisas.

d) Film disjunctions and disintegrations in the cornices.

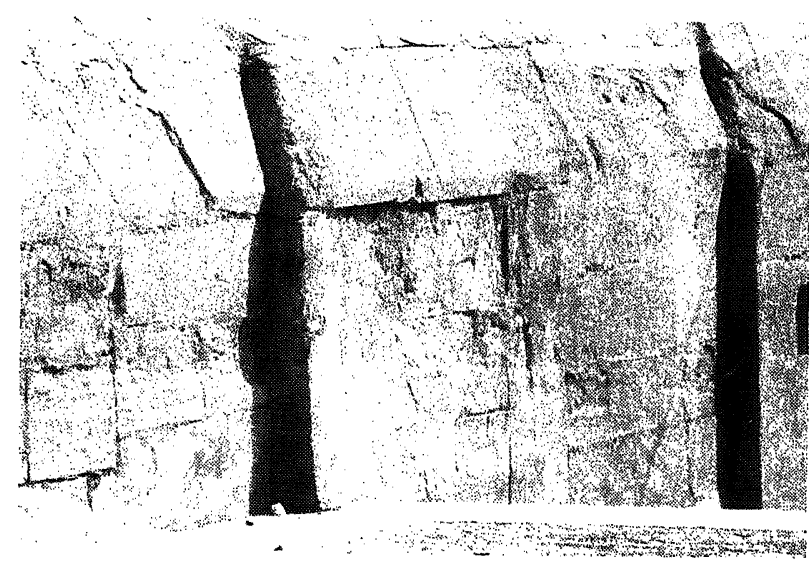

f) Arenizaciones en los zócalos.

f) Grain disgregations in the socles.

Fig. 1.-Indicadores visuales de alteración. Fachada principlal. 1. a lámina.

Fig. 1.-Visual indicators of deterioration. Main Façade. 1. ${ }^{\text {st }}$ picture. 


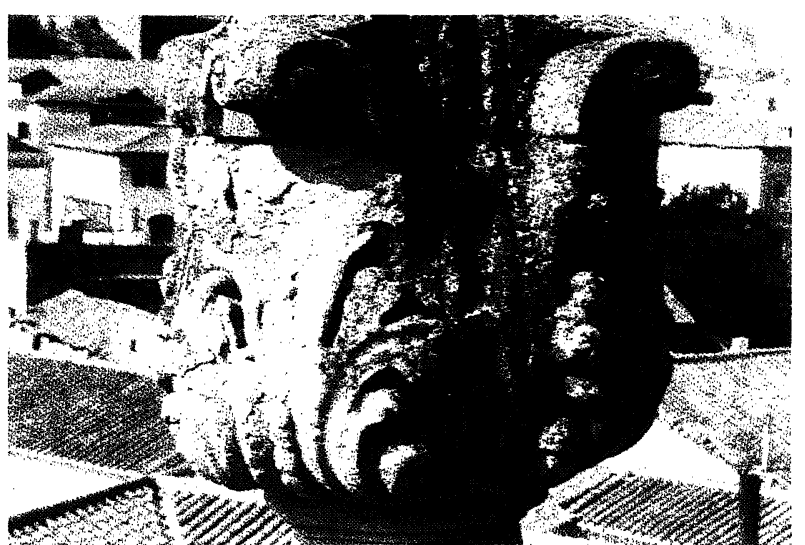

a) Arenizaciones en los pináculos.

a) Grain disgregations in the pinnacles.

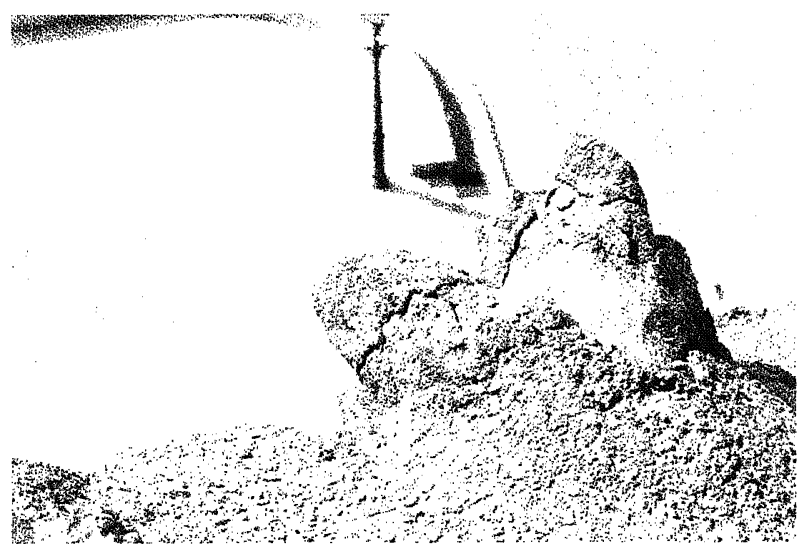

c) Fisuras en adornos.

c) Fissuring in ornaments.

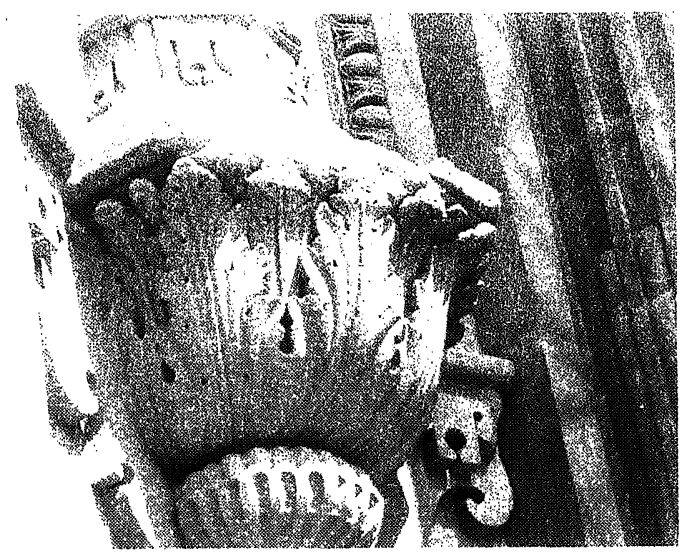

e) Fragmentaciones en capiteles.

e) Spalling in capitals.

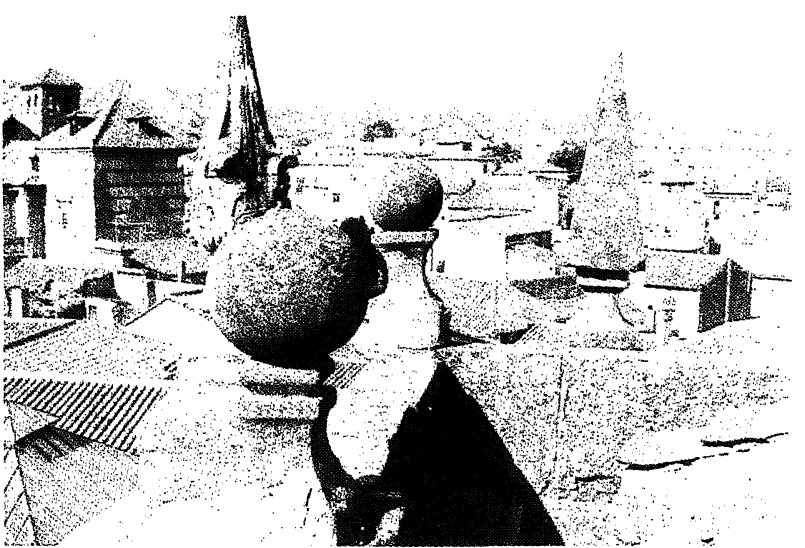

b) Fisuras en los pináculos y bases.

b) Fissuring in the pinnacles and basement.

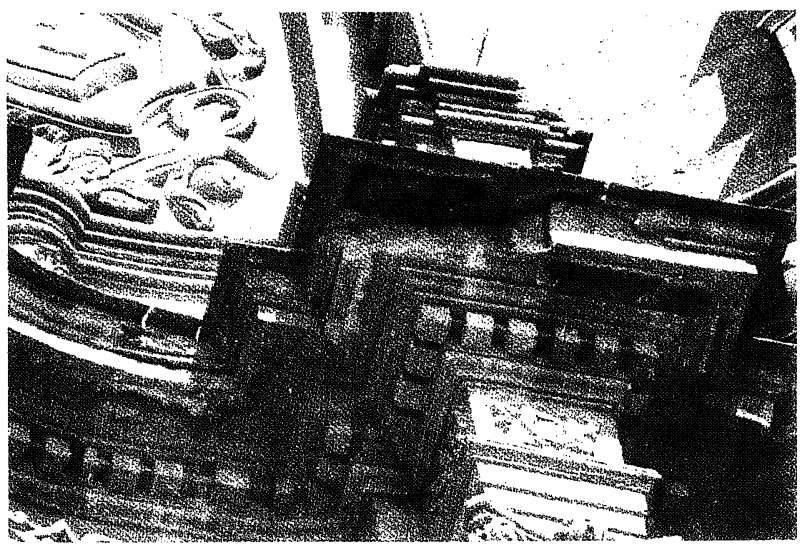

d) Fragmentaciones en las corisas.

d) Spalling in the cornices.

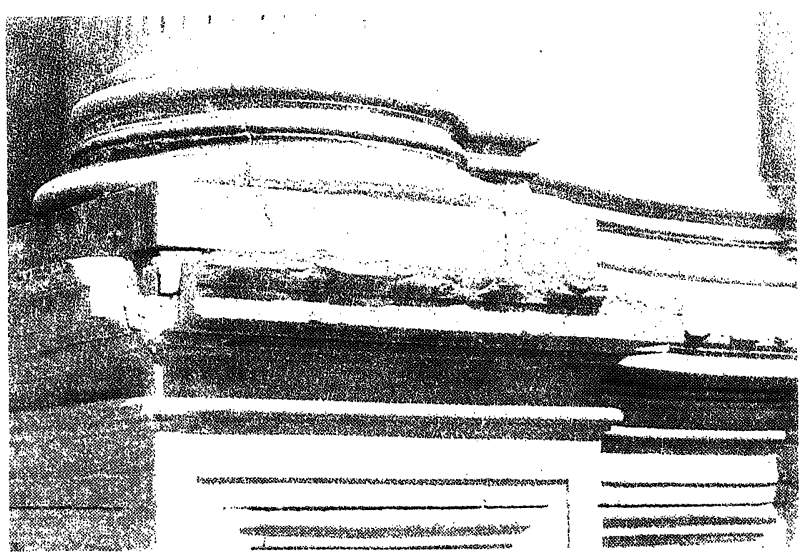

f) Fracturas y fragmentaciones en mármoles.

f) Cracking and spalling in marbles.

Fig. 2.-Indicadores visuales de alteración. Fachada principal. 2. lámina.

Fig. 2.-Visual indicators of deterioration. Main Façade. $2 .^{\text {nd }}$ picture. 
tratamiento antiguo (Fig. 2f). También se observan tinciones por óxidos en las zonas adyacentes a los anclajes de las rejas.

Los mayores depósitos de polvo se dan en las zonas resguardadas del viento y de la lluvia (volúmenes internos, detrás de las columnas, etc.), debajo de las cornisas (Fig. 1c y 2d) y, más evidentes aún, bajo los pliegues de las esculturas de mármol (Fig. 1b). No se encuentran eflorescencias salvo, excepcionalmente y sin interés, en algún episodio causado por aportes de sales de algún mortero cercano.

Los depósitos existentes debajo de las cornisas suelen hacerse coherentes por el desarrollo de microorganismos $\theta$ incluso, a veces, impermeables; los ciclos de humidificación y secado hacen que dichos depósitos se separen de la piedra en forma de disyunción de películas (Fig. 1d) aunque no es éste un fenómeno muy extendido. Sin embargo, sí es más frecuente la disyunción de placas, a veces de más de un centímetro de espesor, que siguen el contorno de las superficies, sobre todo en las más soleadas y cubiertas de líquenes (Fig. 1e). Deformaciones como hinchamientos suelen preceder a estas disyunciones.

Las pérdidas de materia debidas a decohesiones producidas por mecanismos de incremento de volumen en capilares e intersticios (congelación de agua, cristalización de sales, hidratación), donde revisten mayor gravedad es: en los zócalos, en forma de arenizaciones, que suelen venir agravadas por la implantación de morteros de reparación ricos en sales (Fig. 1f); debajo de las cornisas, en forma de disgregaciones (Fig. 1d) que se convierten en arenizaciones allí donde la protección de los aleros se ha perdido y, por tanto, pueden también intervenir mecanismos de disolución; y en los pináculos y florones (Fig. 2a), sobre todo en la orientación a levante que es por donde reciben los primeros rayos del sol cada día. Es de señalar la línea divisoria que aparece en la figura (Fig. 1f) entre dos zonas de diferente grado de alteración. Parece sugerir que ha existido aquí durante muchos años una rampa que ha protegido a la zona inferior de los mecanismos de alteración antes señalados.

La pérdida de materia con formación de huecos apenas tiene representación, salvo cierto picado a la derecha de la portada al nivel del suelo, y algunas pequeñas alveolizaciones en los ángulos de las zonas más altas de esta fachada. Existen algunos otros huecos pero parecen estar más ligados a heterogeneidades del material que a la acción conjunta del viento y la humedad, factores causantes de los mecanismos conducentes a este tipo de alteraciones.

Respecto a los distintos tipos de rupturas que pueden darse, fracturas, fisuras y due to oxides are also observed in the adjacent areas to the grate anchorages.

The biggest deposits of dust are in the areas sheltered from the wind and rain (internal volumes, behind the columns, etc.), under the cornices (Fig. 1c and 2d) and, even more evident, under the folds of the marble sculptures (fig. 1b). Eflorescencies are not found except, exceptionally and with no interest, in some incident caused by the contributions of salts from a nearby mortar.

The existing deposits bellow the cornices usually become coherent due to the development of microorganisms and, sometimes, even become waterproof; the humidification and drying cycles separate these deposits from the stone in the form of film disjunctions (Fig. 1d) although this is not widespread. However, contour scaling which follows the contour of the surfaces is much more frequent, sometimes more than a centimetre thick, especially in the sunbaked areas and those covered by lichens (Fig. 1e). Swelling deformation usually precede these disjunctions.

Where the losses of material due to decohesions produced by mecanisms of volume increase in capilaries and interstices (freezing of water, salt crystallizations, hidration) is more serious are: in the form of grain disgregations, which are usually aggravated by the used of mortars for repair rich in salts (Fig. 1f); below the cornices, in the form of disintegrations (Fig. 1d) which are converted into grain disgregations wherever the protection by eaves has been lost and, therefore, dissolution mecanisms can also intervene; and in the pinnacles and finials (Fig. 2a), above all when oriented to the East where they receive the first rays of the sun everyday. We must point out the dividing line which appears in figure if between two areas of different degrees of deterioration. It seems to suggest that there has been a ramp here for many years protecting the lower areas from the above mentioned deterioration mecanisms.

The loss of material with formation of holes is hardly represented, except certain pitting at ground level to the right of the portal and some alveolar erosions in angles of the higher areas of this façade. There are other holes that seem to result from the heterogeneity of the material rather than to conjunct effect of wind and humidity which are the factors that cause this type of deterioration.

As to the different kinds of ruptures that can be produced, cracks, fisures and spalling, the most 
fragmentaciones, los elementos más efectados son los adornos del último nivel, pináculos, bolas y florones, muchos de ellos en estado de ruina $y$ que en el momento de hacerse este estudio se estaban restaurando. Ya se habían visto sometidos estos elementos a otras reparaciones anteriores, al parecer con poco éxito dado el estado precario en que han vuelto a encontrarse. Algunos de ellos han sido sujetados con alambres para evitar su caída. Las zonas de mayor deterioro suelen ser las bases y las puntas de los pináculos, más expuestas a los saltos térmicos y a los problemas de heladicidad (Fig. 2b). Otros labrados con gran superficie expuesta al aire se ven afectados también por fisuras, como ciertos adornos (Fig. 2C), que pueden llegar a fragmentaciones (Fig. 2d y e). La cruz inserta en lo alto del remate también ha provocado rupturas, probablemente por las diferencias en los coeficientes de dilatación entre el metal y la piedra. Aunque en la bibliografía especializada no parece existir un total acuerdo acerca de la contribución que la gelivación puede prestar a este tipo de alteraciones, la abundancia de éstas en las calcarenitas de las catedrales de Guadix y Granada, donde las temperaturas por debajo de $0^{\circ} \mathrm{C}$ son frecuentes, en contraste con su escasez en las de Sevilla, Cádiz y Almería (Alcalde, 1990), con ausencia de heladas, parece afirmar esta relación factor-indicador en este tipo de piedra.

Los mármoles de la parte inferior de la fachada padecen fracturas, a veces de grandes dimensiones y fragmentaciones, en general pequeñas pero muy numerosas, en las molduras y ángulos. Algunas fracturas, que se prolongan en diferentes bloques, parecen invocar problemas de cargas (Fig. 2f).

En resumen, esta fachada, que por ser la principal está más profusamente decorada y, por tanto, con mayor superficie expuesta al ambiente, que coincide con estar orientada de forma que recibe los vientos dominantes y las primeras radiaciones del sol, se encuentra gravemente afectada por todo tipo de rupturas. Los adornos que la coronan necesitan una acertada reconstrucción, con materiales en concordancia con los factores de alteración a que se van a ver expuestos.

\subsection{Fachada de Santiago}

Se le llamará así por contener la portada de este nombre y por simplicidad, ya que su orientación no coincide con un punto cardinal.

La piedra mayoritariamente empleada es una calcarenita de color amarillo similar a la mencionada en la fachada principal, con diferentes tonalidades según los bloques (Fig. 3a) y a veces con estratos fuertemente coloreados (Fig. 3b). Algunos elementos parecen ser de calizas más compactas, de cierto aspecto marmóreo. affected elements are those found on the last level, pinnacles, globes and finals, many of these are in a state of ruin and were being restored at the time of this study. They had already undergone previous repairs although not very successfully given the precarious state in which they are now found. Some of them have been fastened with wires to stop them falling. The most deteriorated zones are usually the bases and tips of the pinnacles, these being more exposed to thermic jumps and frosts (Fig. 2b). Other carvings with large surfaces exposed to the air were also affected by fissures, such as certain ornaments (Fig. 2c) which can become spallings (Figs. 2d and e). The cross inserted at the top of the crowning has also provoked ruptures probably due to the differencies in coefficients of dilatation between the metal and stone. Although, in the specialized bibliography, there does not seem to be total agreement on the contribution that frost makes to this type of deterioration, the abundancy of these in calcarenites of the Guadix and Granada Cathedrals, where temperatures below $0^{\circ} \mathrm{C}$ are frequent, as opposed to their scarcity in those of Seville, Cadiz and Almería (Alcalde, 1990), with lack of frosts, seems to affirm this factor-indicator relationship in this type of stone.

The marbles of the lower part of the façade suffer cracks, sometimes very big, and spalling, little in general but very numerous, in the chaplets and angles. Some cracks, which are prolonged in different blocks, seem to invoke weight problems.

In summary, as this façade is the main one, is the most profusely decorated, so having a greater surface exposed to the environment, and being oriented in such a way that it receives the dominating winds and first radiations of the sun, it is seriously affected by all types of ruptures. The ornaments which crown it need a correct reconstruction with materials in concordance with the deterioration factors to which they will be exposed.

\subsection{Santiago façade}

It will be called as such for having the portal of this name and for simplicity, as its orientation does not coincide with a cardinal point.

The stone mainly used is yellow calcarenite similar to that mentioned on the main façade with different tonalities in different blocks (Fig. 3a) and sometimes having strongly coloured layer (Fig. 3b). Some elements seem to be of a more compact limestone, with a marmoreal aspect. The socle on the extreme left (San Torcuato Chapel) seems whiter, showing it has been restored. 


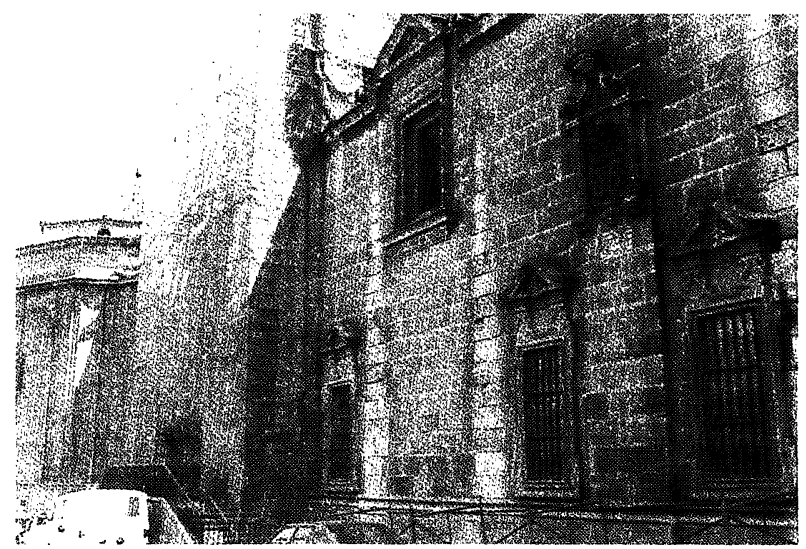

a) Pátina ocre en toda la fachada.

a) Ochre patina all over the façade.

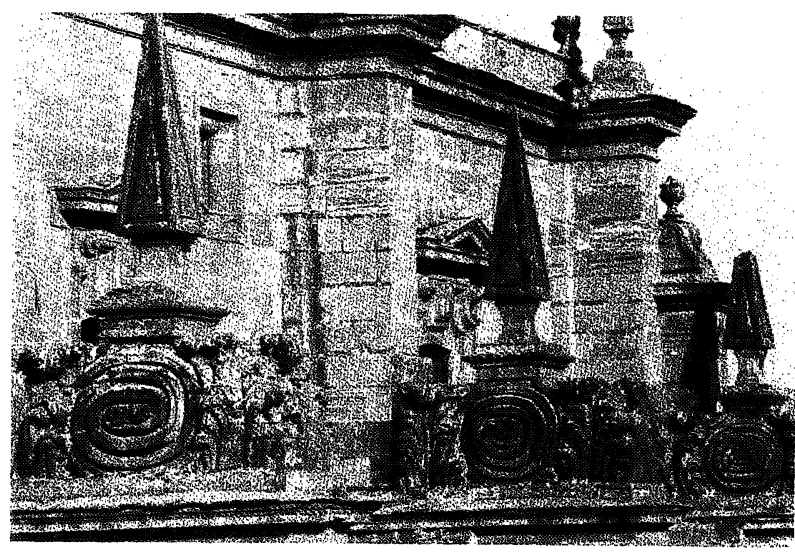

c) Mayor desarrollo de líquenes en superficies orientadas al Norte.

c) Greater growth of lichens on the surfaces facing North.

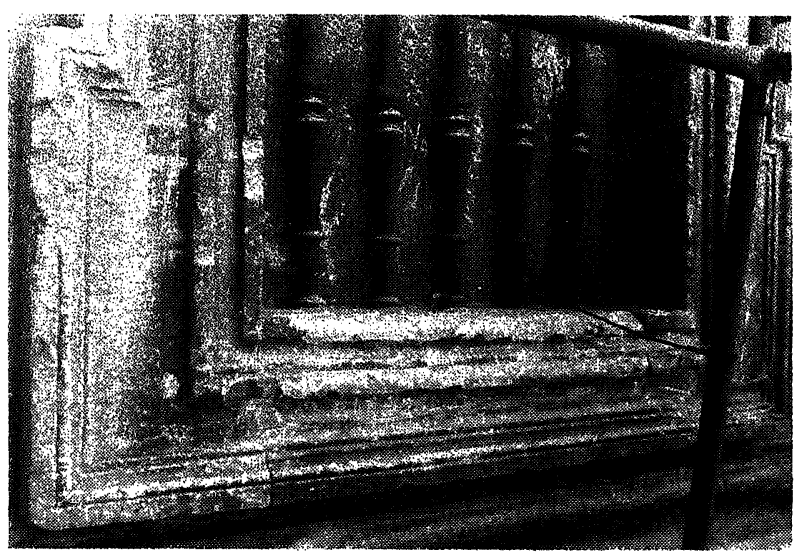

e) Tinciones por rejas de ventanas.

e) Stains caused by the bars.

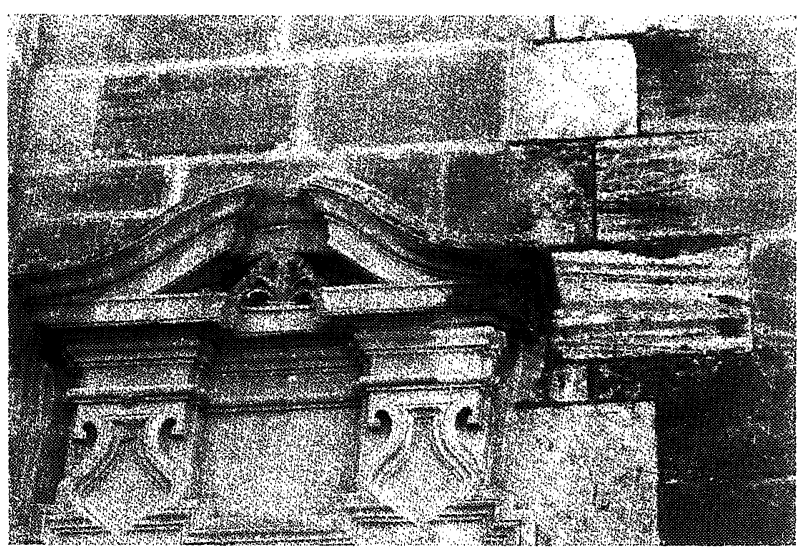

b) Contraste entre zonas con pátina y depósitos y zonas lavadas.

b) Contrast between washed areas and those with patina and deposits.

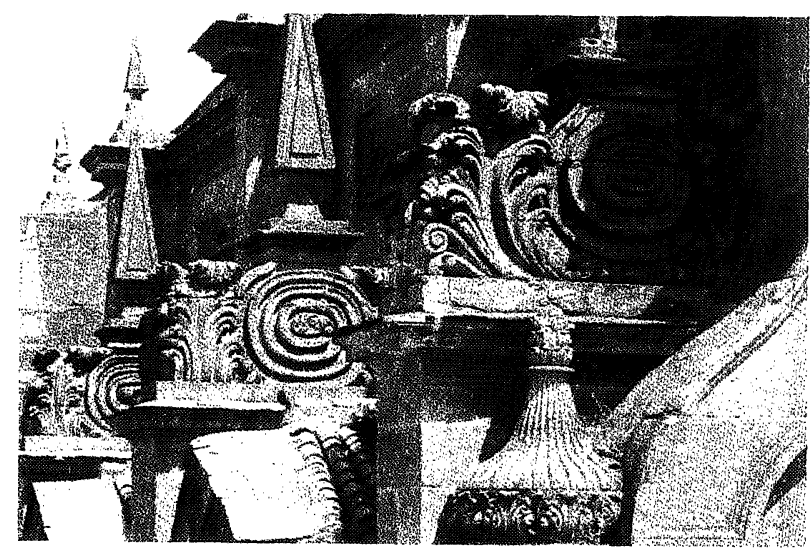

d) Menor desarrollo de líquenes en superficies orientadas al Sur.

d) Smaller growth of lichens on the surfaces facing South.

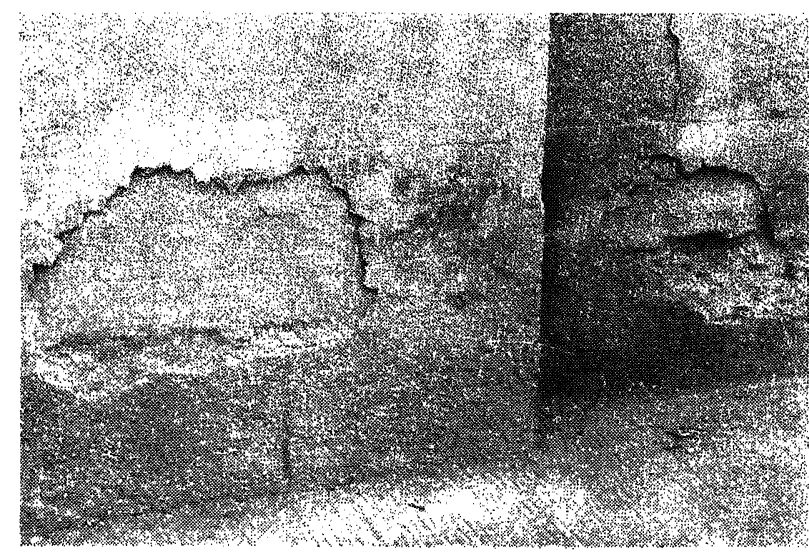

f) Disyunciones por morteros en zócalos.

f) Disjunctions by mortars on the socles.

Fig. 3. - Indicadores visuales de alteración. Fachada de Santiago. 1." lámina.

Fig. 3.-Visual indicators of deterioration. Santiago Façade. $1 .^{\text {st }}$ picture. 


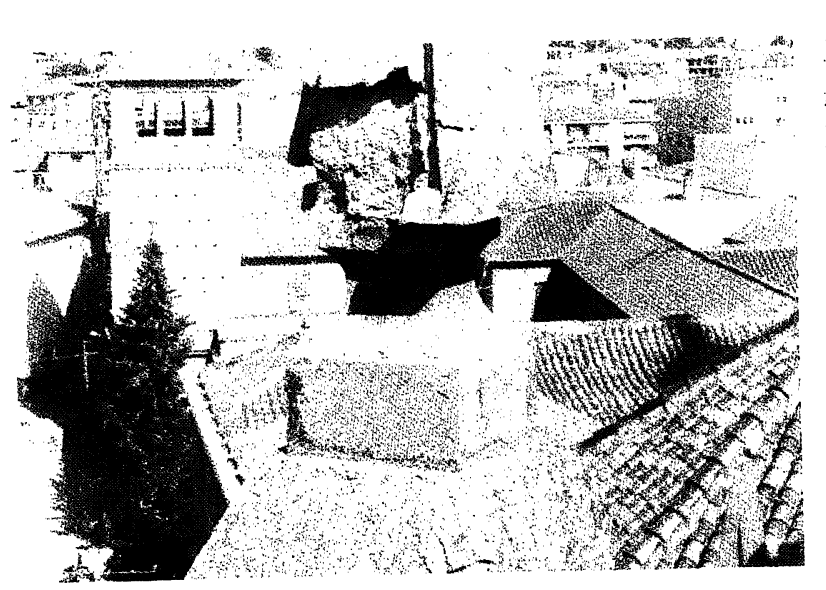

a) Disyunciones y arenización a causa de morteros en los pináculos.

a) Disjuctions and grain disgregations by mortars in the pinacles.

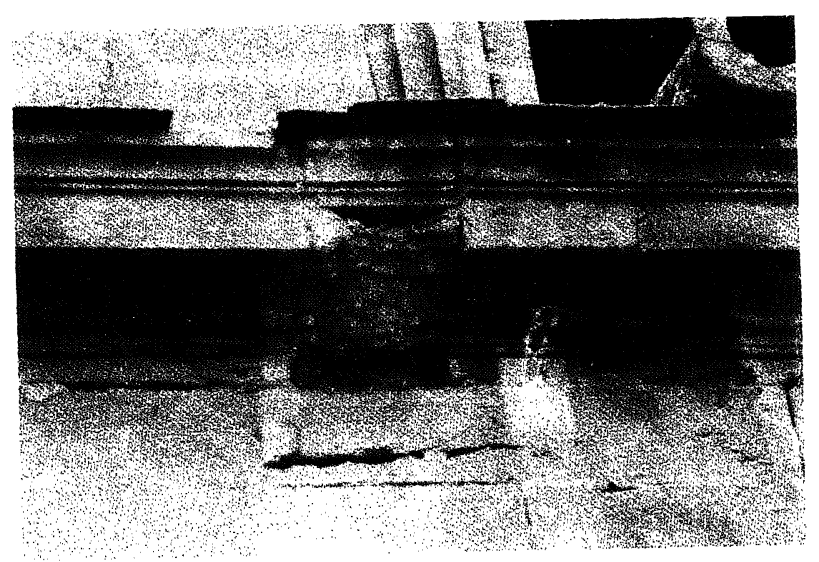

c) Arenizaciones en las cornisas.

c) Grain disgregations in the cornices.

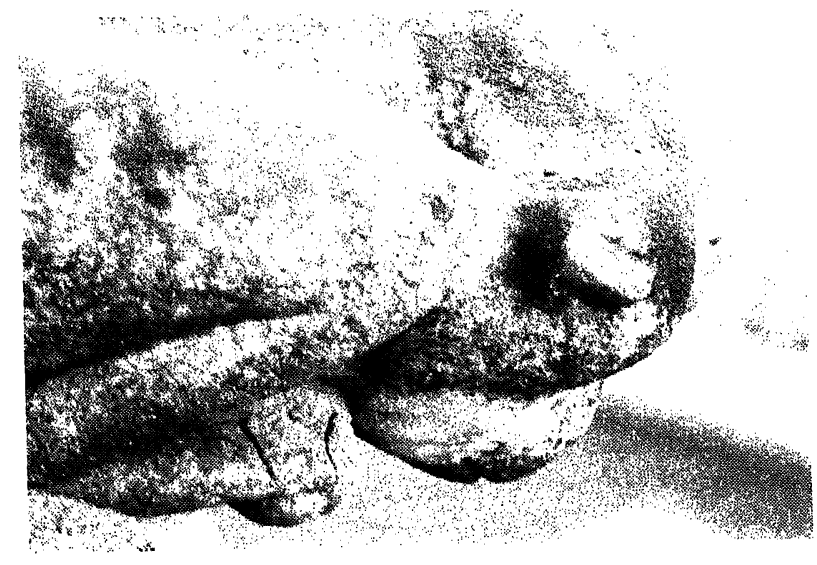

e) Fisuras y fragmentaciones en las gárgolas.

e) Fissuring and spalling in the gargoyles.

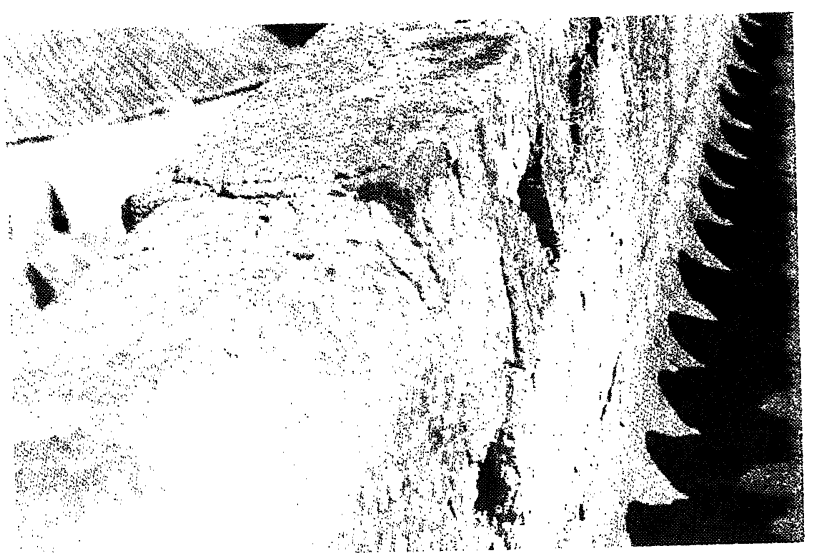

b) Disyunciones de placas y arenización en los antepechos

b) Contour scaling and grain disgregations in the parapets.

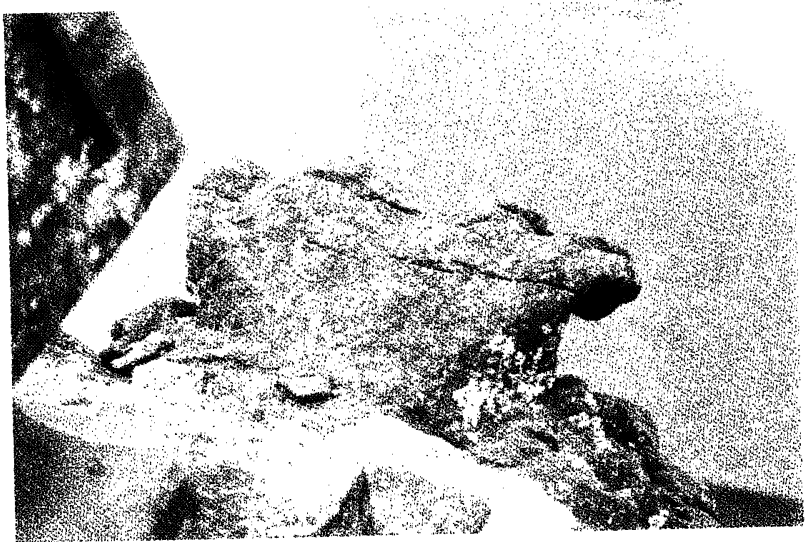

d) Fisuras en los adornos.

d) Fissuring in the ornaments.

Fig. 4.-Indicadores visuales de alteración. Fachada de Santiago. 2." lámina.

Fig. 4.-Visual indicators of deterioration. Santiago Façade. ${ }^{\text {st }}$ picture. 
El zócalo del extremo izquierdo (capilla de San Torcuato) aparece más blanco, mostrando que ha sido restaurado; se han empleado materiales de reposición, sobre todo en las molduras que coronan dicho zócalo. También existen numerosas reparaciones hechas con morteros, sobre todo en los antepechos, pináculos y zócalos. En el momento de hacerse este estudio, la portada está en restauración.

Por su orientación al Suroeste, esta fachada recibe el sol durante la tarde y es bien barrida por los vientos. La precede una calle estrecha con poca circulación que hace suponer una escasa contaminación atmosférica. Existe alguna humedad ascendente que alcanza poca altura desde el suelo.

Como agentes biológicos hay que señalar los líquenes, más abundantes en las superficies orientadas al Norte (Fig. 3c) que en las orientadas al Sur (Fig. 3d); también en las horizontales como los antepechos y la parte superior de las gárgolas. Hay algunas plantas superiores en las zonas altas.

Además de la pátina ocre que afecta a toda la fachada (Fig. 3a y b), se observan tinciones debajo de las ventanas causadas por las rejas (Fig. 3e). Los depósitos de polvo se acumulan en zonas protegidas de la lluvia, como debajo de las cornisas, en los frisos y en los tímpanos de las ventanas, lo que queda resaltado por el contraste con las zonas lavadas por el agua que cae de las gárgolas (Fig. 3b y 4c). Son mayores en el primer nivel que en los superiores, y más en el lienzo que queda a la izquierda de la portada que a la derecha. Apenas se observan depósitos de guano salvo en una ventana a la izquierda de la portada en que hay un nido de palomas.

Las disyunciones existentes son más de morteros de reparación que de piedras, aunque en su desprendimiento arrastran parte del material pétreo; esto afecta fundamentalmente a los zócalos (Fig. 3f), pináculos (Fig. 4a) y antepechos (Fig. 4b). En este último caso se aprecian también disyunciones de placas biológicas.

\section{Las disgregaciones y arenizaciones por} mecanismos de disolución y de cristalización e hidratación de sales se dan fundamentalmente en las cornisas, alli donde la rotura de los aleros permite el paso del agua (Fig. 4c), y en los pináculos y antepechos, sobre todo en aquellos que han recibido sales de morteros (Fig. $4 a$ y b).

Los picados no son frecuentes; los más abundantes, con algún caso de alveolización se dan en la pared de la capilla de San Torcuato que se encuentra más orientada al Sur, más expuesta por tanto a los vientos canalizados por la calle, y en las zonas lavadas por el agua que cae de las gárgolas.
Replacement materials have been used, above all, in the chaplets that crown sais socle. Numerous repairs with mortar also exist, especilly on the parapets, pinnacles and socles. At the time of this study the portal is undergoing restoration.

Due to its South Western orientation this façade receives the sun during the afternoon and is well swept by winds. There is a norrow street with light traffic in front of it which means there is very little atmospherical contamination. There is some rising damp which only reaches up a little above ground level.

We can point out lichens, more abundant on surfaces facing North (Fig. 3c) than the South (Fig. 3d), as biological agents; there are also some on the parapets and upper part of the gargoyles. There are some superior plants on the high areas.

Stains are observed under the windows caused by the bars (Fig. 3e) as well as ocher patinas all over the façade (Figs. 3a and b). The dust deposits are accumulated in areas sheltered from the rain, such as under the cornices, in the friezes and the tympanums of the windows which contrast greatly with the areas washed by water that falls from the gargoyles (Figs. $3 b$ and $4 c$ ). The are larger on the first level than on higher ones and more so on the stretch from the left of the portal to the right. Guano deposits are hardly seen except on one window to the left of the portal where there is a pigeon nest.

The existing disjunctions are more of repair mortars than of stone, although their fall pulls down part of the petreous material; this basically affects the socles (Fig. 3f), pinnacles (Fig. 4a) and the parapets (Fig. 4b). In the last case biological plaques disjuntions also appear.

Disintegrations and grain disgregations by dissolution, salt crystallization and hydratation mechanisms are basically found on the cornices, where the breaking of eaves lets water through (Fig. 4c), and on the pinnacles and parapets, above all in those which have received mortar salts (Figs. $4 a$ and b).

Pitting is not frequent; the most abundant, with an ocassional case of alveolar erosion are found on the San Torcuato Chapel wall which is more orientated to the South and so more exposed to the winds channelled by the street and in the areas washed by water falling from the gargoyles. 
Las rupturas en todos sus tipos son el indicador de alteración más ostensible en esta fachada, como en toda la catedral. Afectan, sobre todo, a los elementos más esculpidos como los que adornan la portada (Fig. 4d), a las gárgolas (Fig. 4e) y a los pináculos (Fig. 4f). La evolución fractura-fisura-fragmentación, originada en primer lugar por oscilaciones térmicas y seguida de la penetración de agua y congelación durante las heladas parece ser corroborada aquí también sobre todo en los extremos de los pináculos que, o bien se encuentran fragmentados o bien han sido reparados (Fig. 3c), y en las orejas y extremos de las alas de las gárgolas que representan animales (en peor estado las orientadas al Sur). Las bases de los pináculos también se ven afectadas de múltiples fisuras (Fig. 4a). Fracturas y pequeñas fragmentaciones existen en las calizas blancas de apariencia más compacta de algunas ventanas. Los antepechos también presentan abundantes fisuras (Fig. 4b).

En resumen, la mayor degradación en esta fachada se da en los pináculos y las gárgolas, muchos de ellos fragmentados y lo que aún queda, con abundantes fisuras por las que penetra el agua y no tardarán en fragmentarse si no se toman las medidas adecuadas.

\subsection{Fachada de cabecera}

Se encuentra separada de la residencia episcopal por una calle estrecha, existiendo un pasillo de comunicación sobre un arco. Entre la capilla de San Torcuato y la sala capitular existe un volumen adosado que corresponde a ciertas dependencias del templo.

De la piedra empleada (Fig. 5a) se pueden hacer las mismas consideraciones que en la fachada anterior; añadir, si acaso, que las piedras con estratos fuertemente remarcados por diferentes coloraciones han sido más profusamente utilizados en el último nivel de cerramiento de la girola (Fig. 5b).

Por su orientación al Noroeste esta fachada es la más umbría y húmeda de todas por lo que los agentes biológicos, líquenes, musgo e incluso plantas superiores adquieren mayor desarrollo que en las demás, sobre todo en la parte más protegida, en el nivel más bajo por encima de los volúmenes adosados (Fig. $5 c$ y d).

La pátina ocre característica se resalta por el contraste con algunas superficies que carecen de ella por haber tenido adosados algún tipo de construcción o por haber sido lavadas por chorros de agua. Esta pátina se hace muy oscura en las superficies de las ventanas protegidas por mallas metálicas (Fig. $5 d$ y $\theta$ ).
All types of ruptures are the indicator of the most ostensible deterioration on this façade as in all the Cathedral. They affect, above all, the more sculptured elements such as those which adorn the portal (Fig. 4d), the gargoyles (Fig. 4e) and the pinnacles (Fig. 4f). The cracking-fissuringspalling evolution originated at first by thermic oscillations and followed by water penetration and freezing during frosts, seems to be corroborated here also, above all on the tops of the pinnacles, which are either spalled or have been repaired (Fig. 3c), and in the ears and wing tips of the gargoyles that represent animals (those oriented to the South are in a worse state). The bases of the pinnacles have also been affected by multiple fissures (Fig. 4a). Cracks and small spalling exist in the white limestone which appear more compact in some windows. The parapets also show abundant fissures (Fig. 4b).

In summary, the greatest degradation on this façade is found on the pinnacles and gargoyles, many of them spalled and those which remain have abundant fissures through which water penetrates and they will not take long in fragmenting if adecuate measures are not taken soon.

\subsection{Sanctuary Façade}

It is separated from the episcopal residence by a narrow street although a communication passage exists above an arch. An addorsed building exists between the San Torcuato chapel and the capitulary saloon which corresponds to certain offices of the temple.

The stone used (Fig. 5a) is the same as the previous façade; we can add, perhaps, that the stones with strongly marked layers by different colors have been used profusely on the last level of the closing of the apse aisle (Fig. 5b).

This façade is the dampest and shadiest of all due to its North Western orientation and so the biological agents, lichens, moss and even superior plants acquire a greater development than on the others, specially in the most sheltered part on the lowest level above the addorsed buildings (Figs. $5 c$ and $d$ ).

The characteristic ocher patina stands out against some other surfaces that lack this, as they have had some kind of building addorsed or for having been washed with jets of water. This patina is very dark on the surfaces of the windows protected by metallic netting (Fig. $5 d$ and e). 


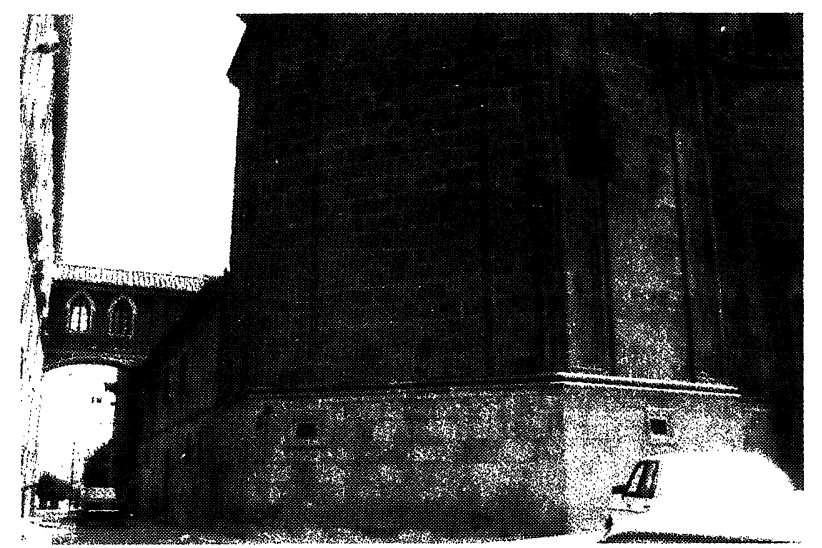

a) Litotipos empleados en la fachada.

a) Lihtotypes used in the façade.

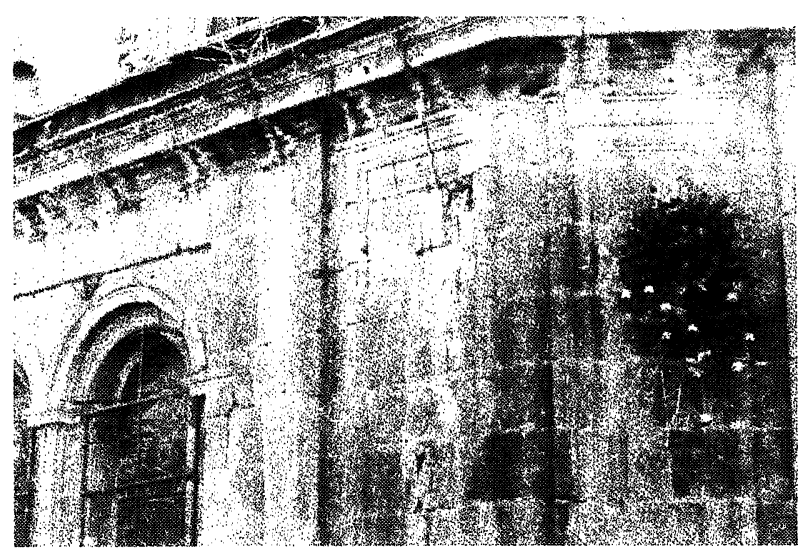

c) Existencia de plantas superiores.

c) Growth of superior plants.

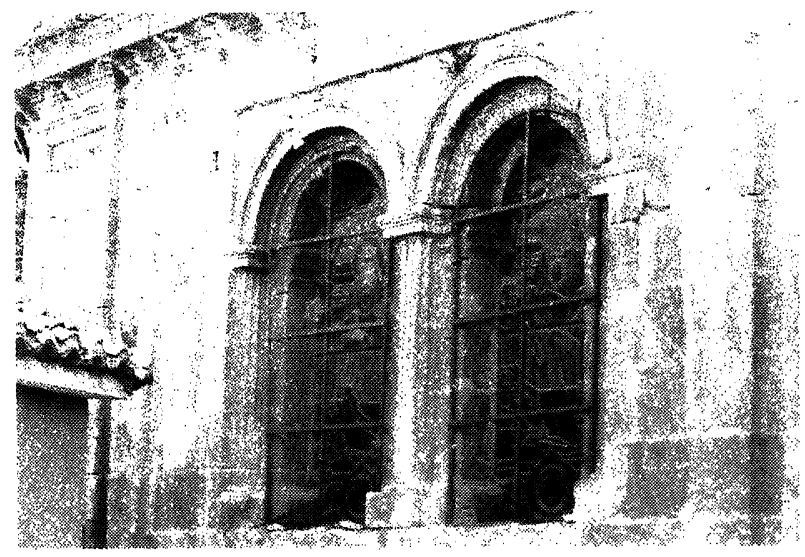

e) Pátinas oscuras en las ventanas con mallas metálicas.

e) Dark patinas in the windows with metallic netting.

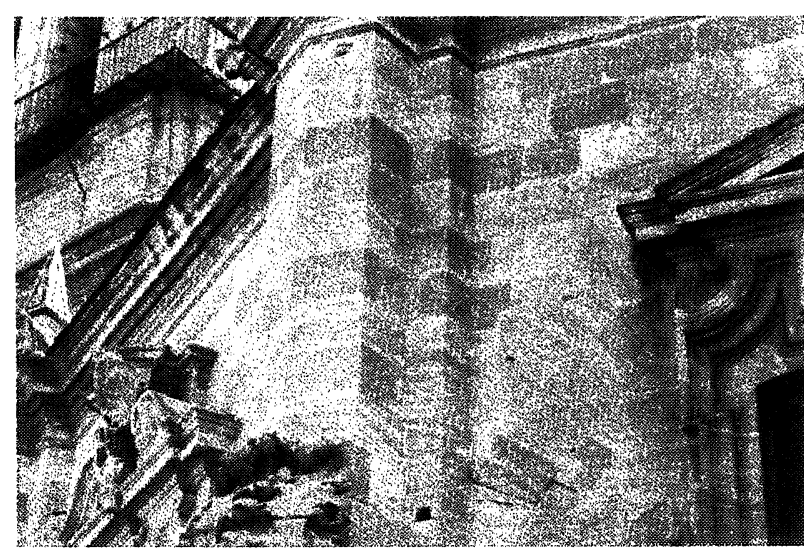

b) Estratificación de ciertos litotipos.

b) Stratification in same lihtotypes.

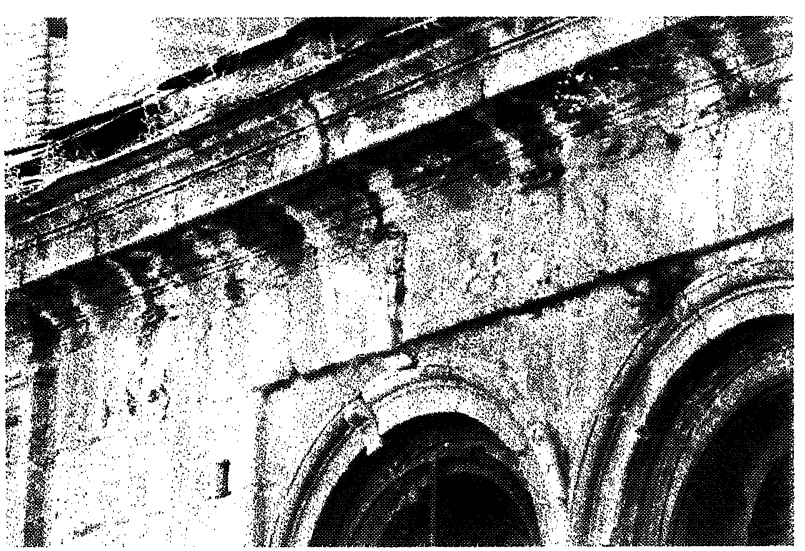

d) Gran desarrollo de líquenes.

d) Large development of lichens.

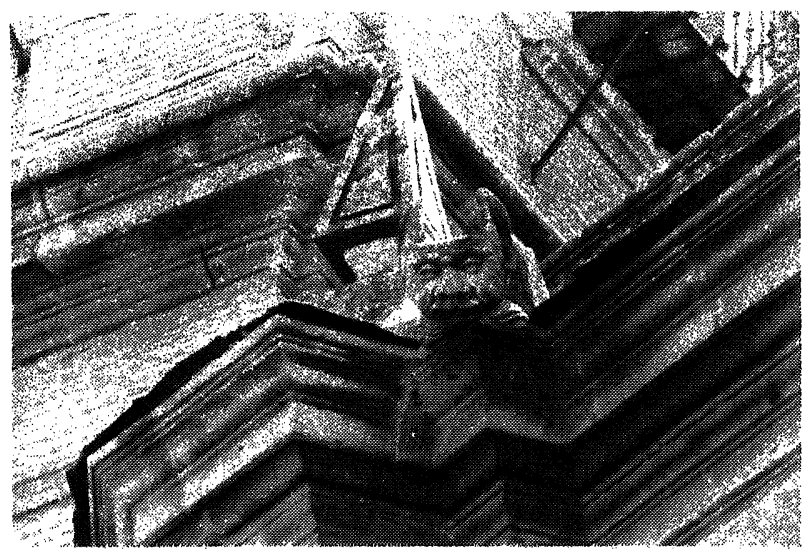

f) Depósitos debajo de las cornisas.

f) Deposits under the cornices.

Fig. 5.-Indicadores visuales de alteración. Fachada de Cabecera. 1. lámina.

Fig. 5. - Visual indicators of deterioration. Sanctuary Façade. 1. ${ }^{\text {st }}$ picture. 


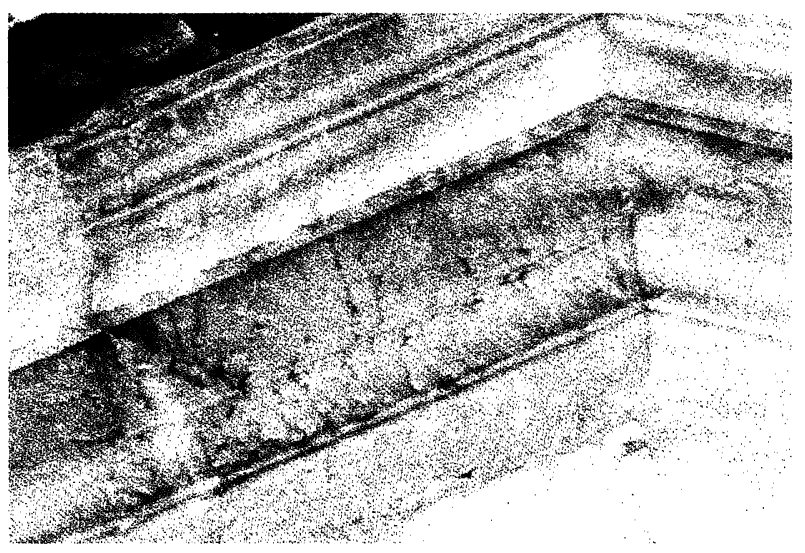

a) Disyunciones de películas debajo de las cornisas.

a) Film disjunctions under the cornices.

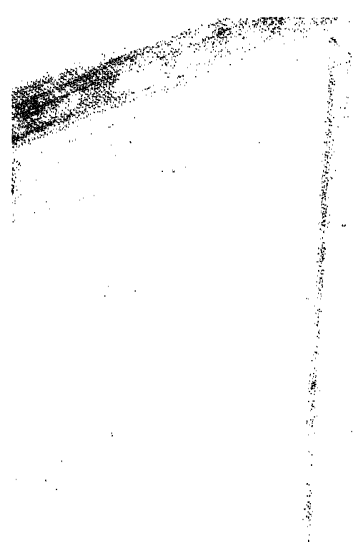

c) Disgregación generalizada en toda la fachada.

c) Generalized disintegration all over the façade

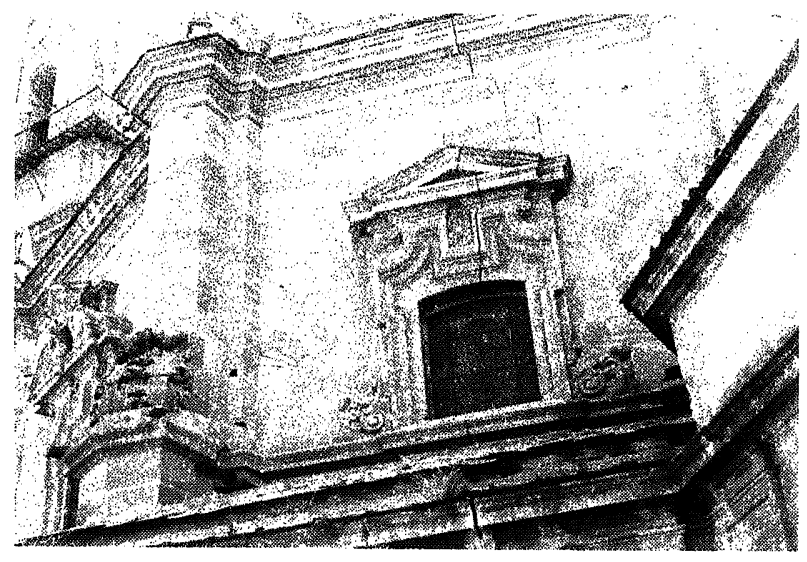

e) Fisura causada por cargas o por seismos.

e) Fissuring caused by weight or by earthquakes.

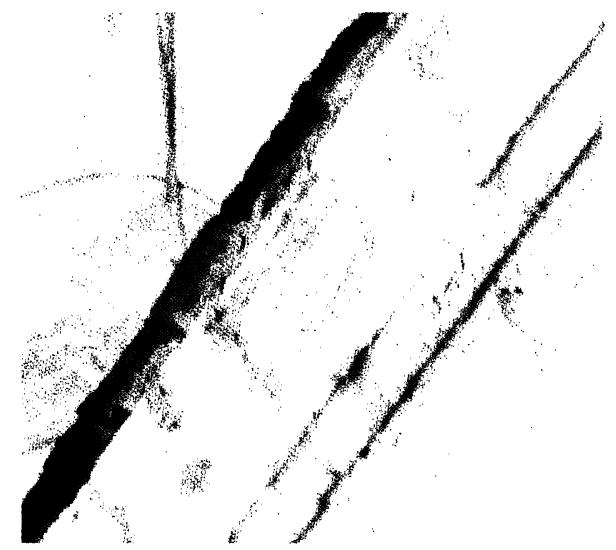

b) Disgregaciones debajo de las cornisas.

b) Disintegrations under the cornices.

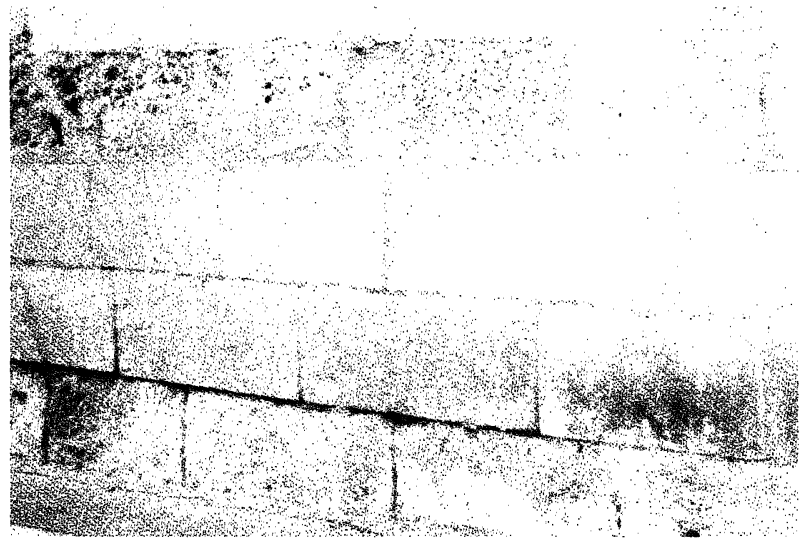

d) Arenizaciones y algunas alveolizaciones.

d) Grain disgregations and some alveolar erosion

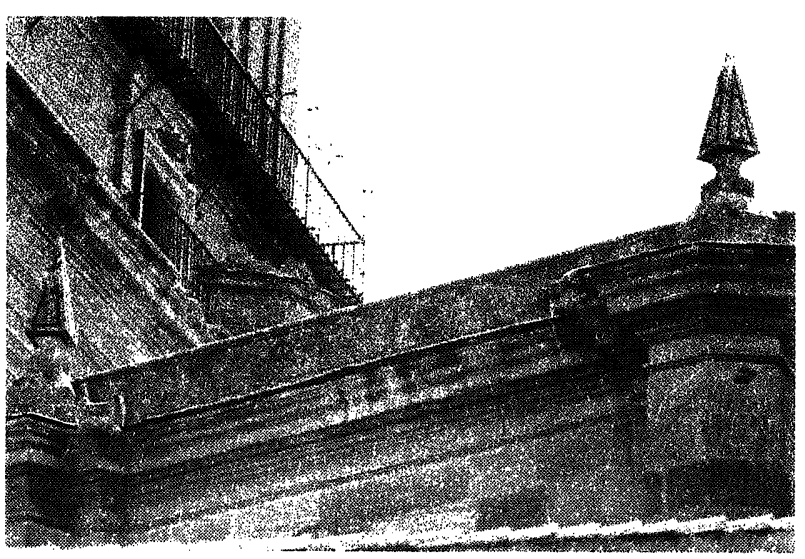

f) Fragmentación de los extremos de los pináculos.

f) Spalling in the tops of the pinnacles.

Fig. 6. - Indicadores visuales de alteración. Fachada de cabecera. 2. ${ }^{\text {a lámina. }}$

Fig. 6. - Visual indicators of deterioration. Sanctuary Façade. 2. ${ }^{\text {nd }}$ picture. 
Los depósitos son abundantes en toda la fachada, mayores debajo de las cornisas (Fig. 5f), y más en los niveles bajos donde quizás se constituyan en lechos de algas, desprendiéndose en forma de disyunciones de películas (Fig. 6a).

Las disgregaciones se generalizan más que en las otras fachadas (Fig. 6c), aumentando en las cornisas (Fig. 6b) y al nivel del suelo (Fig. 6d).

Tanto los picados (Fig. 5f) como las alveolizaciones (Fig. 6d) siguen teniendo carácter episódico.

En esta orientación son mucho menos importantes las rupturas. Hay una gran fisura vertical que atraviesa toda la fachada (Fig. 6e) pero es evidente que ha sido ocasionada por problemas de cargas del edificio o de seismos. Los extremos de los pináculos también sufren fragmentaciones, en general restauradas (Fig. 6f) pero, en cambio, las gárgolas se conservan en muy buen estado (Fig. 5f), al contrario que en las otras fachadas.

En resumen, lo más característico de esta fachada es la abundancia de agentes biológicos que demandan una limpieza y tratamiento con productos que impidan su reproducción. Las alteraciones de la piedra alcanzan mayores extensiones de superficie pero son menos profundas que en las demás, quedando la fachada menos degradada.

\subsection{Fachada del campo}

Junto con esta fachada se estudiará la torre, situada en su extremo Norte. Al Sur se encuentra adosada la iglesia del Sagrario y una sala de capítulos (Fig. 7a).

Los materiales pétreos son similares a los empleados en la fachada opuesta. La torre, excepto en su primer cuerpo, cornisas y huecos, se ha construido con ladrillo. El cupulín que la corona está revestido de planchas, posiblemente de cinc. Varias superficies, en especial de la iglesia del Sagrario y sus dependencias, están enfoscadas.

Orientada al Nordeste, solo se encuentra soleada en las primeras horas de la mañana. Situada en alto, da a un gran espacio abierto que se inicia con un paseo peatonal y un jardín. No existe humedad ascendente apreciable.

Los agentes biológicos presentes van desde los líquenes hasta las plantas superiores (Fig. 7b y 8 b) adquiriendo una gran proliferación en las superficies cercanas a la iglesia del Sagrario orientadas al Norte, y en las adyacentes.
The deposits are abundant all over the façade, greater under the cornices (Fig. 5f) and more so on lower levels where there are alga nest which fall down as film disjunctions (Fig. 6a).

Disintegrations are generalized more than on other façade (Fig. 6c) increasing under cornices (Fig. 6b) and at ground level (Fig. 6d).

\section{Pitting (Fig. 5f) as well as alveolar erosions}

(Fig. 6d) still have an episodic character.

Ruptures are much less important in this orientation. There is a great vertical fissure which crosses all the façade (Fig. 6e) but it is evident that it has been caused by weight problems or earthquakes. The tops of the pinnacles also undergo spalling, usually restored (Fig. 6f), yet the gargoyles are in a good state (Fig. 5f), as oposed to other façades.

In summary, the most characteristical of this façade is the abundance of biological agents which calls for a cleaning and treatment with products which impede their reproduction. The deterioration in the stone cover a more extensive area but are less deep than in the others and so leaving the façade less degraded.

\subsection{Countryside Façade}

The tower, situated at the Northern end, will be studied together with façade. The Sagrarium church and a capitulary saloon (Fig. 7a) are joined to this façade to the South.

The petreous materials are similar to those employed on the opossing façade. The Tower, except its first body, cornices and openings have been built with brick. The small dome which crowns it has been covered by metal sheets, possibly zinc. Several surfaces are stuffed with mortar, specially the Sagrarium church and its dependencies.

Oriented to the North East, it is only sunned in the early hours of the morning. It is situated on high and faces a great open space which is started with a pedestrian walk and a garden. There does not exist any appreciable rising damp.

The biological agents present range from lichens to superior plants (Figs. $7 b$ and $8 b$ ) acquiring a great proliferations on surfaces near the Sagrarium church oriented to the North and those adjacent. 
La pátina ocre vuelve a estar presente en toda la fachada, siendo más oscura en el primer cuerpo de la torre (Fig. 7c), donde una línea divisoria separa dos niveles de diferente tonalidad en la misma (Fig. 7a). Hay tinciones debajo de las ventanas con rejas (Fig. $7 \mathrm{c}$ ).

Esta fachada está bastante limpia de depósitos; algunos debajo de las cornisas acompañados, como es habitual, de disyunciones de películas, en general de carácter biológico (Fig. 7d), y de disgregaciones en zonas cercanas al paso de agua o donde los aleros se han roto. También hay disyunciones de placas en los antepechos (Fig. 7e). Los picados siguen siendo escasos, como en todo el edificio, y las alveolizaciones son muy esporádicas (Fig. 7f).

Todas las molduras y elementos angulares padecen pequeñas fragmentaciones típicas de las dilataciones por oscilaciones térmicas, más abundantes en las piedras más compactas (Fig. 8a). Algunos bloques de los antepechos tienen fisuras que los atraviesan en toda su longitud (Fig. 8b) pero los elementos que más las padecen, acompañadas de arenizaciones, son los pináculos y sus bases, muchos en estado de ruina (Fig. $8 \mathrm{c}$ ). Algunos han sido simplemente reparados con cemento (Fig. $8 d$ ) y otros se han intentado reconstruir con morteros, al parecer de la misma piedra (Fig. 8e), pero en ambos casos ya han vuelto a aparecer fisuras. Otros se encuentran ya completamente destruidos (Fig. 8f).

\section{La torre}

Los indicadores de alteración en la torre tienen el interés de que muestran los efectos que la orientación y la altura tienen en los factores de alteración. Se hará referencia sólo a los que afectan a materiales pétreos, como son los de las cornisas, excepto en la del último nivel que también es de ladrillo.

Así, puede observarse que las orientadas al Norte están menos alteradas que las orientadas al Sur. En la cornisa superior del tercer cuerpo orientada al Nordeste (Fig. 9a), se observan sólo algunas desagregaciones y en la orientada al Noroeste (Fig. 9b), disgregaciones con cierto aumento en los agentes biológicos, sobre todo en las juntas entre bloques. La orientada al Sureste en el mismo nivel (Fig. 9c) presenta disgregaciones y algunas arenizaciones; éstas aumentan en la orientada al Suroeste (Fig. 9d), sobre todo en el friso, sumándose algunas

fragmentaciones.

En niveles más bajos (Fig. 9e) aumentan las arenizaciones y los depósitos, siendo evidentes los efectos de los hierros de los balcones (Fig. 9f).
The ocher patina is again present all over the façade, being darker on the first body of the Tower (Fig. 7c), where a dividing line separates two levels of different tonalities (Fig. 7a). There are stains below the windows with bars (Fig. 7c).

This façade is quite clean of deposits; there are some under the cornices accompanied, as is usual, by film disjunctions, usually biological (Fig. 7d), and disintegrations in areas near the passing of water or where the eaves are broken. There is also contour scaling on the parapets (Fig. 7e). Pitting is scarce as in all the building and alveolar erosions are very sporadic (Fig. 7f).

All the molding and angular elements suffer from slight spalling, typical of the dilations due to thermic oscillations, being more abundant in the more compact stones (Fig. 8a). Some blocks on the parapet have fissures which go through their entire length (Fig. 8b) but the elements more affected from them joined with grain disgregation, are the pinnacles and their bases, many of which are in a state of ruin (Fig. 8c). Some have simply been repaired with cement (Fig. 8d) while they have tried to reconstruct others with mortar, seemingly with the same stone (Fig. 8e), yet in both cases fissures have reappeared. Others are completely destroyed (Fig. 8f).

\section{The tower}

The indicators of deterioration on tower are interesting as they show the effects that orientation and height can play in deterioration factors. Only those which affect the petreous materials will be referred to, such as on the cornices except at the last level that is also brick.

So it can be seen that those facing North are less deteriorated than those facing South. We can see only a few disaggregations in the superior cornice of the third body facing North East (Fig. 9a), and disintegrations with a certain increase in biological agents, above all in the unions betwween blocks, on the one facing North West (Fig. 9b). The one facing South East on the same level (Fig. 9c) shows disintegrations and some grain disgregations; these increase on the one facing South West (Fig. 9d), especially on the frieze, with the addition of spalling.

On lower levels the grain disgregations and deposits increase, and the effects of the iron from balconies are evident. 


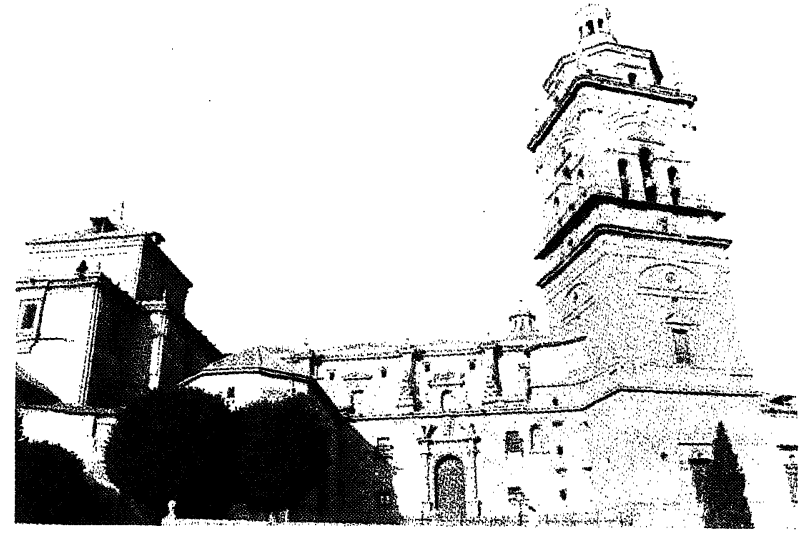

a) Vista general de la fachada.

a) General view of the façade.

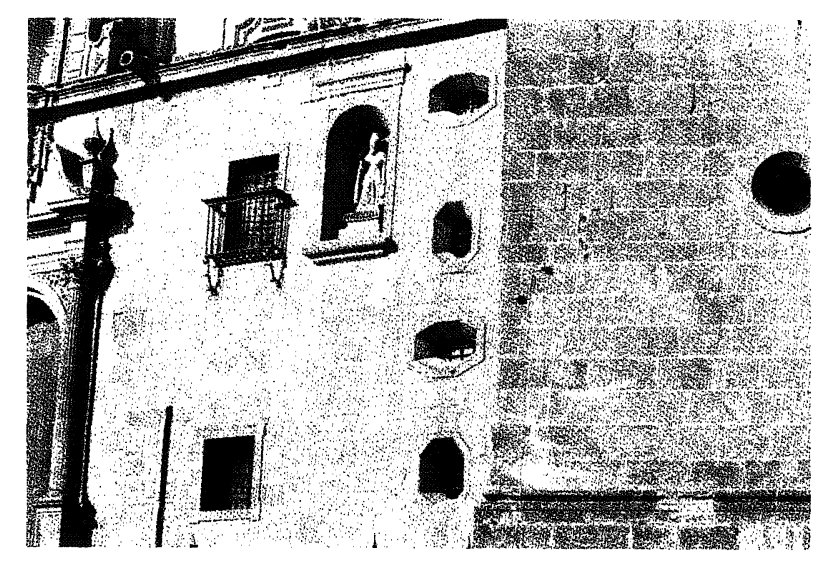

c) Pátina, más fuerte al pie de la torre.

c) Darker patina on the first body of the tower.

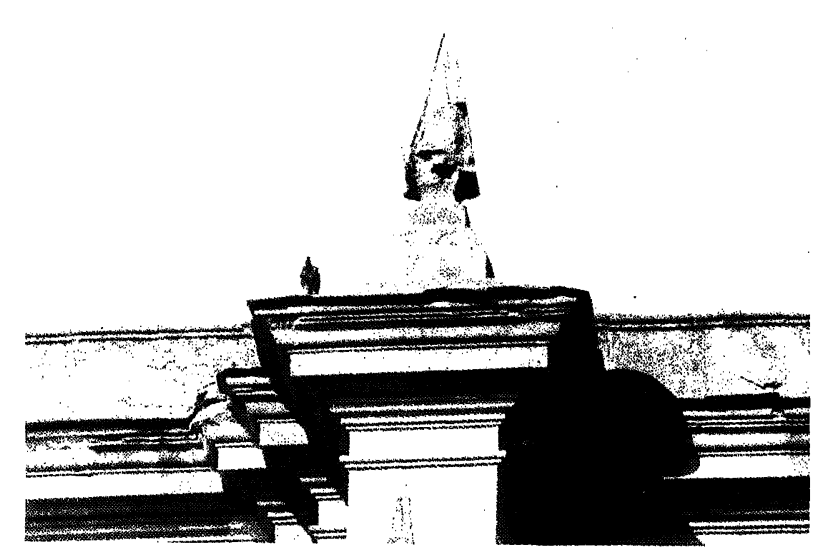

e) Disyunción de placas en antepecho. Arenización en cornisas y pináculos.

e) Contour scaling in the parapets Grain disgregation in cornices and pinnacles.

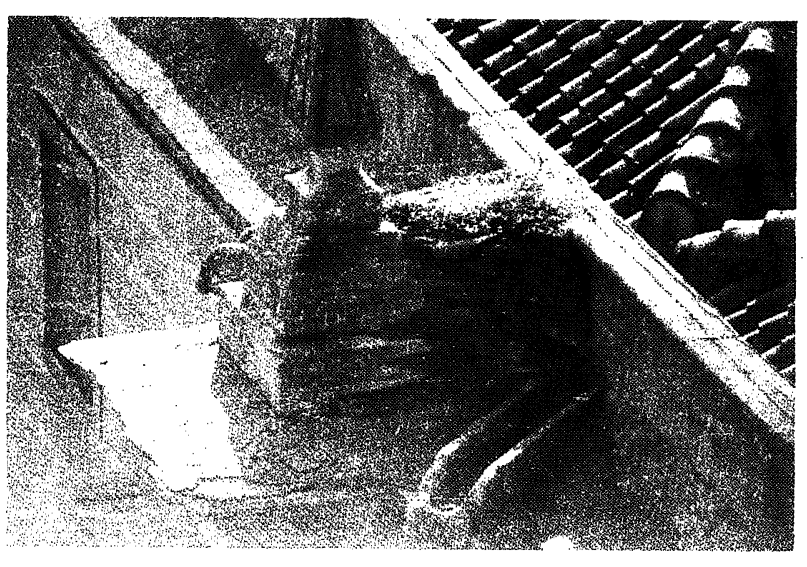

b) Líquenes y plantas superiores.

b) Lichens and superior plants.

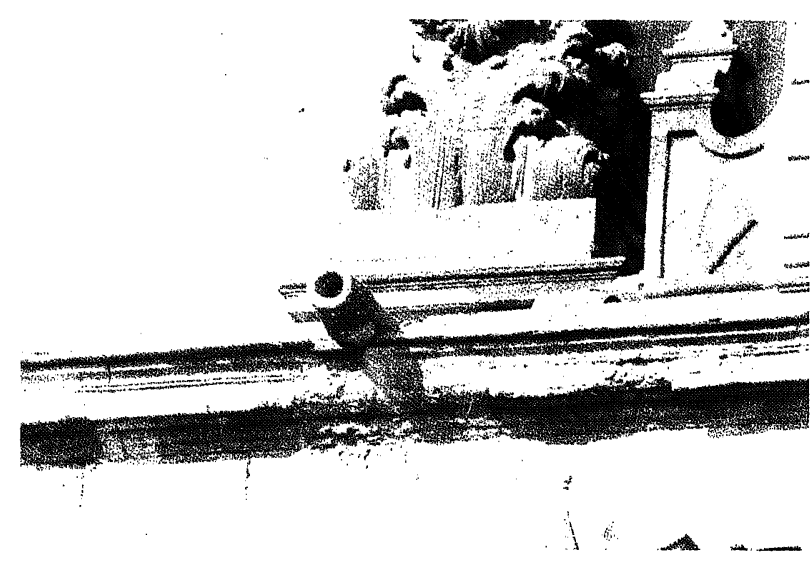

d) Disyunciones de películas y disgregaciones en cornisas.

d) Film disjunctions and disintegrations in the cornices.

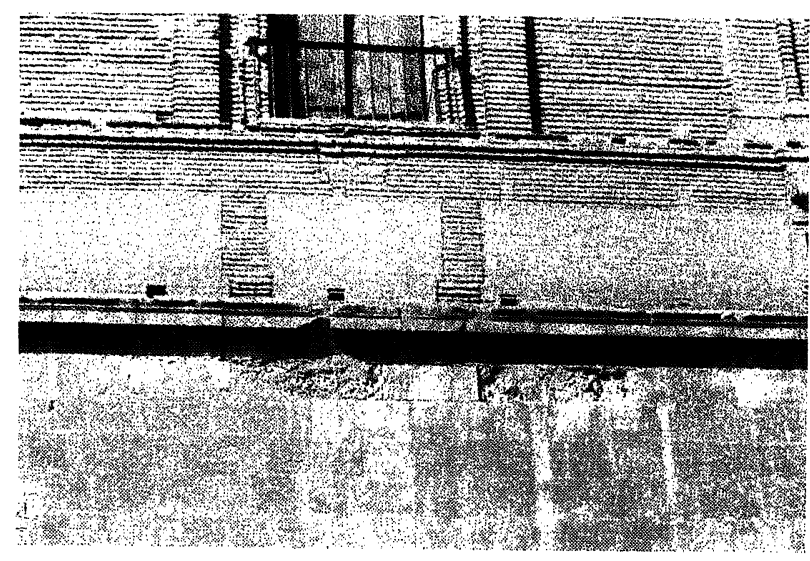

f) Algunas alveolizaciones. Fragmentaciones en ángulos

f) Some alveolar erosions. Spalling in angles of the comices.

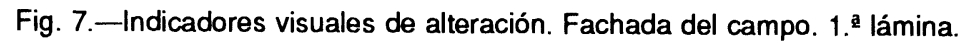

Fig. 7.-Visual indicators of deterioration. Countryside Façade. 1. ${ }^{\text {st }}$ picture. 


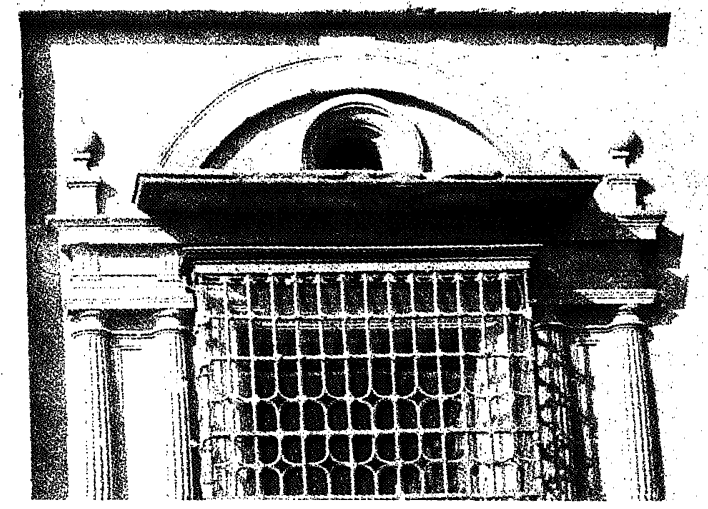

a) Pequeñas fragmentaciones en todas las molduras y ángulos.

a) Slight spalling all over molding and angles.

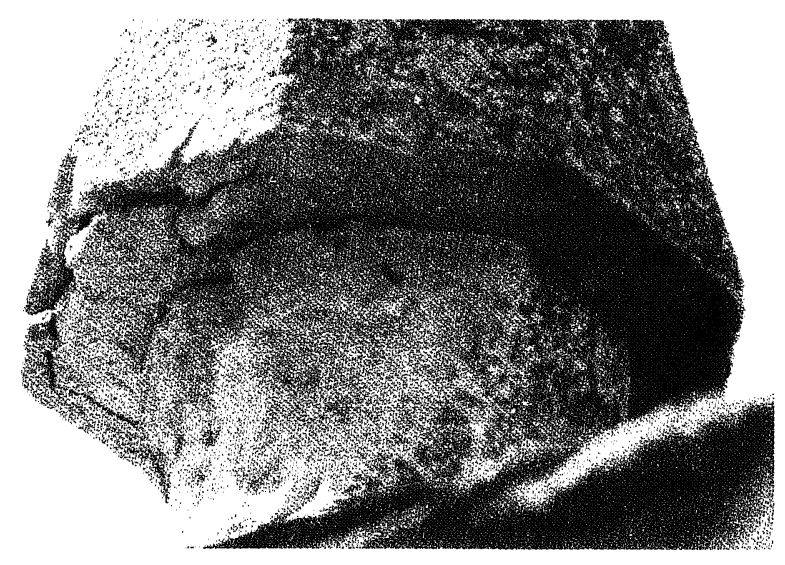

c) Arenizaciones, fisuraciones y fragmentaciones en los pináculos.

c) Grain disgregations, fissuring and spalling in the pinnacles.

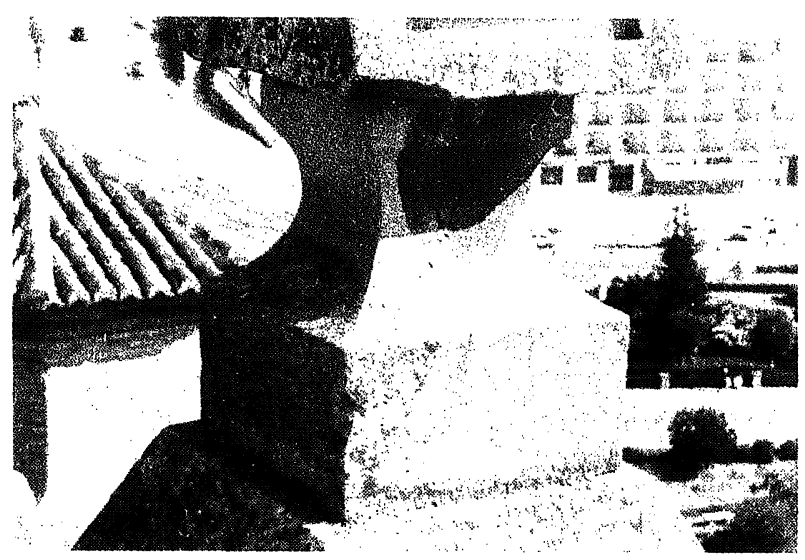

e) Fisuraciones en reconstrucciones hechas con morteros de la piedra.

e) Fissuring in reconstructions made by mortars of the stone.
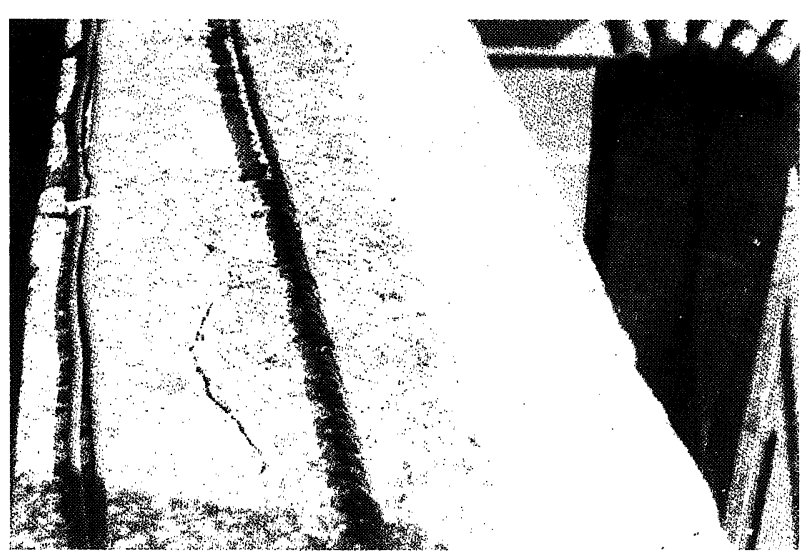

b) Grandes fisuras en los antepechos.

b) Large fissures in the parapets.

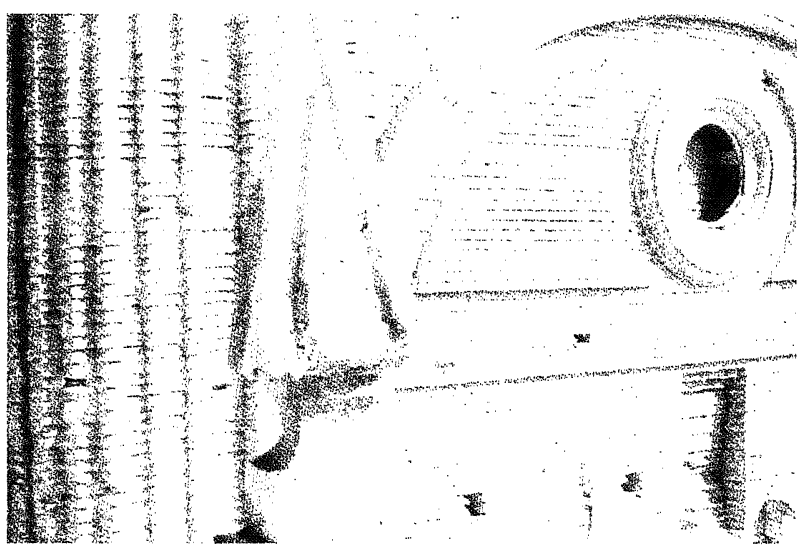

d) Fisuraciones y reparaciones con cemento.

d) Fissuring and repairs made by cement.

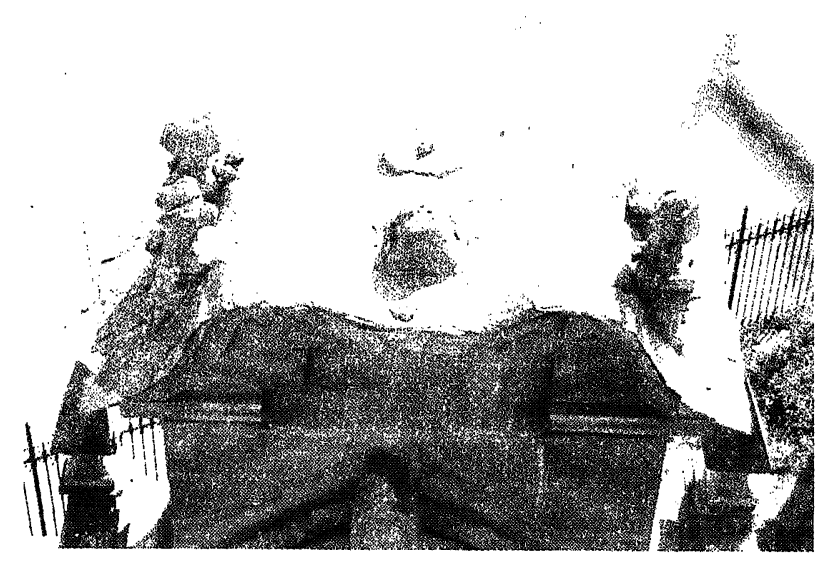

f) Total ruina de pináculos.

f) Total ruin of the pinnacles.

Fig. 8. - Indicadores visuales de alteración. Fachada del campo. 2. lámina.

Fig. 8. - Visual indicators of deterioration. Countryside Façade. $2 .^{\text {nd }}$ picture. 


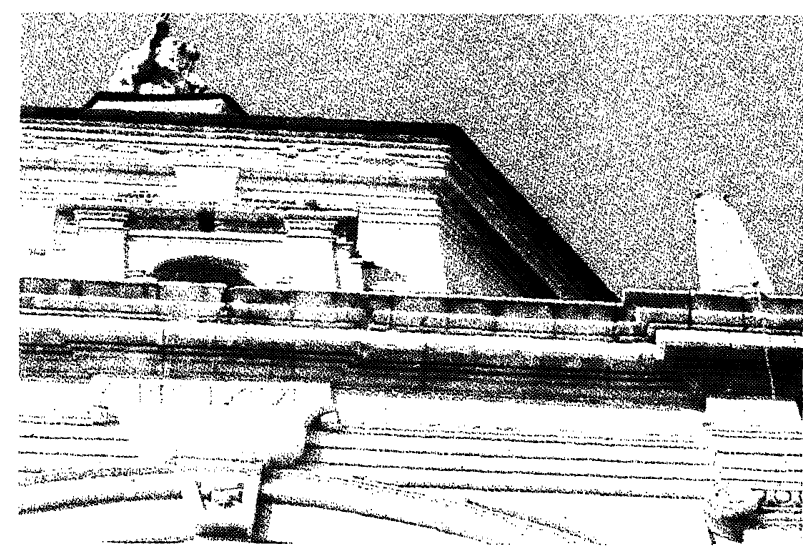

a) Orientación Nordeste. Nivel 3. Desagregaciones.

a) Nort East orientation. 3. ${ }^{\text {rd }}$ level. Disaggregations.

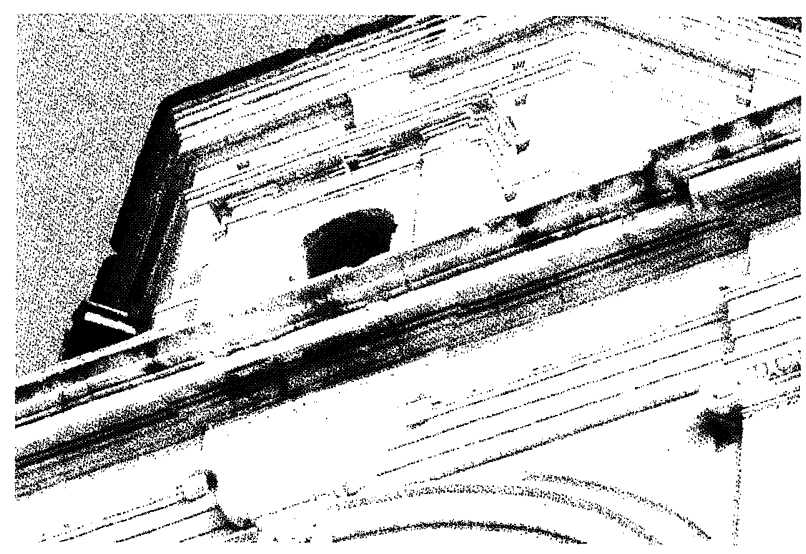

c) Orientación Sudeste. Nivel 3. Disgregaciones $y$ arenizaciones.

c) South East orientation. 3. ${ }^{\text {rd }}$ level. Disintegrations and grain disgregations.

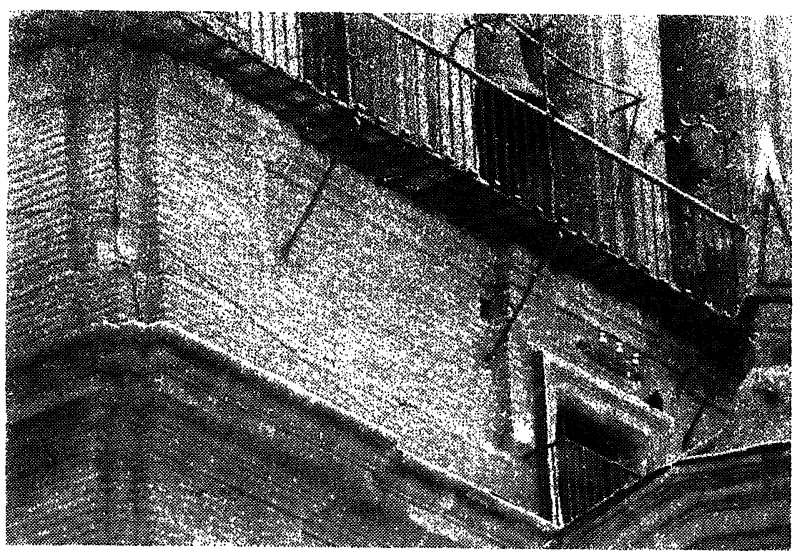

e) Orientación Suroeste. Nivel 2. Arenizaciones y depósitos.

e) South West orientation. 2. ${ }^{\text {nd }}$ level. Grain disgregations and deposits.

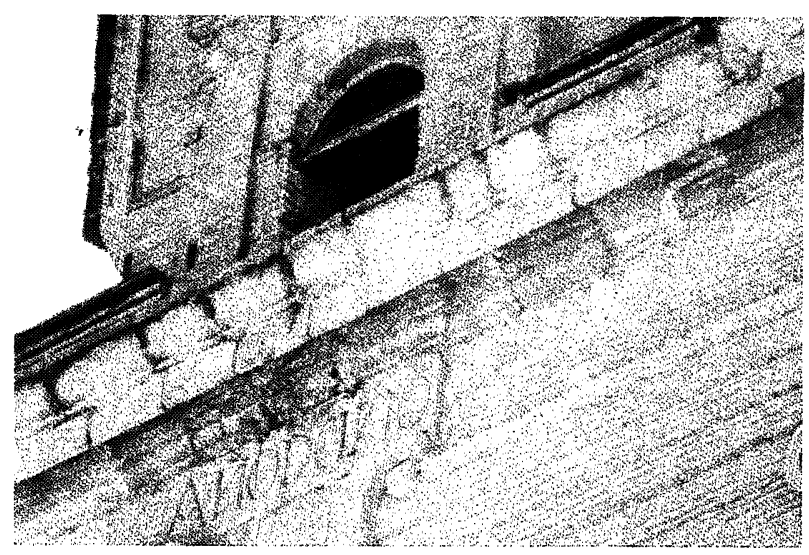

b) Orientación Noroeste. Nivel 3. Disgregaciones y agentes biológicos.

b) North West orientation. 3. ${ }^{\text {rd }}$ level. Disintegrations and biological agents.

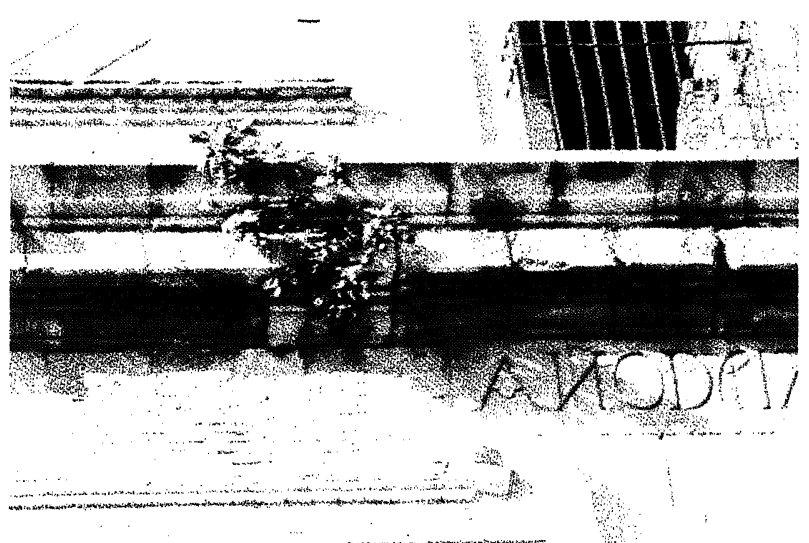

d) Orientación Suroeste. Nivel 3. Arenizaciones y fragmentaciones.

d) South West orientation. $3 .^{\text {rd }}$ level. Grain disgregation and spallin.

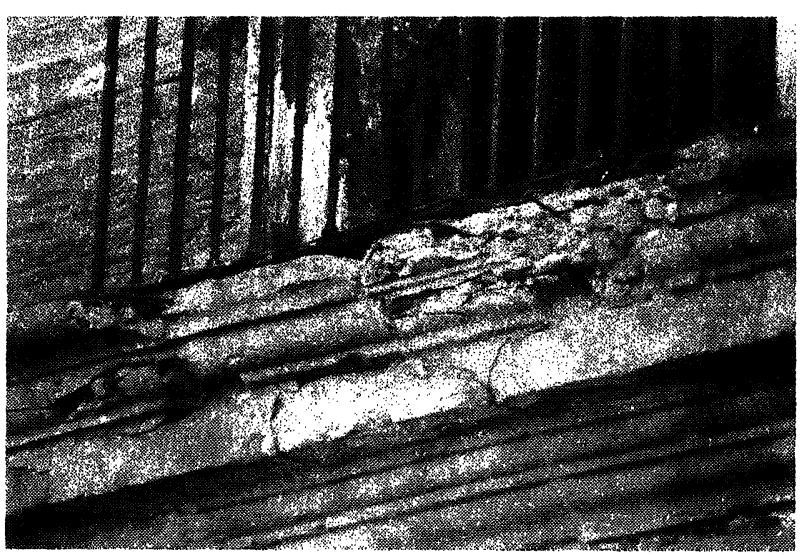

f) Orientación Suroeste. Nivel 2. Efecto de los hierros.

f) South West orientation. 2. ${ }^{\text {nd }}$ level. Effects of the irons.

Fig. 9.-Indicadores visuales de alteración. Torre.

Fig. 9.-Visual indicators of deterioration. Tower. 
De los pináculos que coronan el tercer cuerpo, el que se encuentra en peor estado, afectado por picado en general y por arenización en dos de sus bloques, es el situado en la esquina Sur, seguido del situado en la esquina Este,

fragmentado.

En resumen, esta fachada presenta un estado de alteración intermedio al de las dos anteriores, excepto en los pináculos que están muy degradados, como en toda la catedral.
The pinnacle crowning the third body on the Southern corner is the one in worse state affected by pitting in general and by grain disgregation in two of its blocks. This is followed by the one on the Eastern corner which has spalling.

In summary, this façade is in a state of deterioration intermediate to the other precedent two except on the pinnacles that are very degraded as all the cathedral.

\section{BIBLIOGRAFIA}

ALCALDE, M.: Sintomatología de alteraciones de las Catedrales de Sevilla, Cádiz y Almeria. Ed. Universidad de Sevilla. 1990.

ALCALDE, M.; VILLEGAS, R. et al.: Diagnosis y tratamiento de la piedra. Monografia n. ${ }^{2} 400$. ICCET. Madrid, 1990.

ASENJO, C.: La Catedral de Guadix. Granada, 1977.

Atlas Climático de España. INM. Madrid, 1983.

FERNÁNDEZ, F. J.: Guía de Guadix. Guadix, 1990.

FONT, I.: Climatología de España y Portugal. INM. Madrid, 1983.

MARTIN, A.: Ensayos y experiencias de alteración en la conservación de obras de piedra de interés histórico-artístico. Ed. Ceura Madrid, 1990.

\section{publicaciones del ICCET/CSIC}

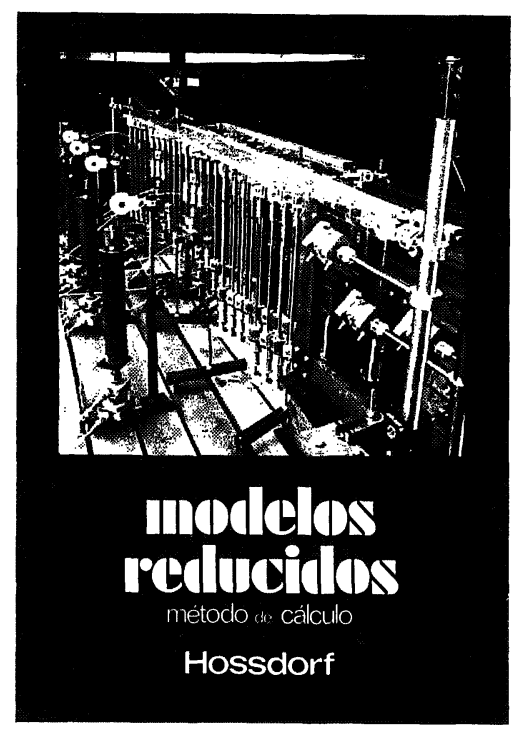

Modelos reducidos. Método de cálculo

H. Hossdorf, Ingeniero Civil

La técnica de los ensayos en modelos reducidos de estructuras sufre hoy dia una decisiva metamorfosis. Hasta hace poco era un medio más bien de artesania, que no siempre era tomado en serio por los académicos teorizantes para comprender el comportamiento resistente de las estructuras complejas $y$ al que se acudió las más de las veces, como a un último remedio debido a sus indiscutibles insuficien cias. Sin embargo, en poco tiempo y gracias a su conexión con los ordenadores digitales, se ha transformado en un instrumento cientificamente valioso que no puede quedar a un lado en la práctica diaria del Ingeniero Proyectista.

Un volumen encuadernado en cartoné plastificado con lomo de tela, de $17 \times 24 \mathrm{~cm}$, compuesto de 250 páginas, 158 figuras $y$ fotografias.

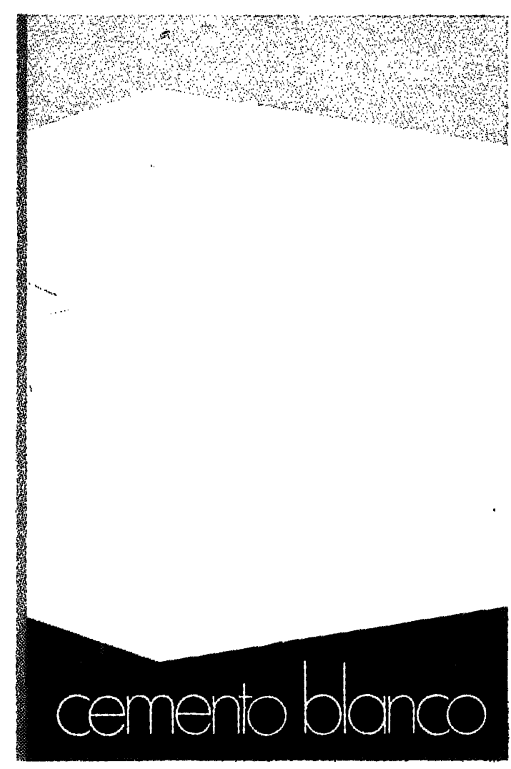

Cemento blanco

Juliản Rezola

Incyeniero Quimico Dipl. I. Q. S

Sabido es que existe una extensa y documentada bibliografia sobre el cemento gris: en cambio, no puede decirse lo mismo ace del cemento portland blanco, ya que los escritos existentes se refieren tan solo a ya ques peciliosidades aue le distinguen

El autor nos ofrece sus profundos conocimientos y su larga experiencia tanto en laboratorio como en fabricación.

La parte descriptiva del libro se complementa con gráficos, diagramas y fotografias de gran utilidad, destinados a conseguir la aplicación apropiada de

Un volumen encuadernado en cartoné policerado, de $17,4 \times 24,3 \mathrm{~cm}$, compuesto de 395 páginas. numerosas figuras, tablas y ábacos.

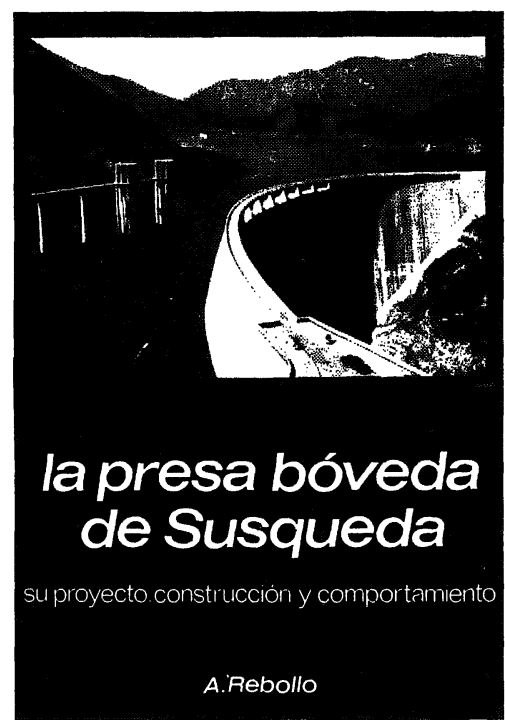

La presa bóveda de Susqueda

A. Rebollo,

Dr. Ingeniero de Caminos

El esfuerzo del constructor de presas se situa por su pretensión de perennidad, a contracorriente de las tendencias de la civilizacion actual, caracte rizada por to fungible. Pueden evocarse las 10.000 grandes. presas en funcionamiento o en construcción que están envejeciendo $y$ reclaman los cuidados gerontológicos para mantener y perfeccionar su servicio $y$ garantizar su inalienable pretensión de perennidad. En la medida en que todas nuevas obras, grandes o pequeñas, son portadoras de

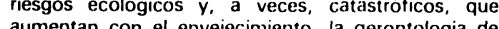
aumentan con el envejecimiento, la gerontologia de las presas es todo un emplazo. La accion adelantada a segur mebolo ento a gevoción parerna que ama su propia obra con

Un volumen encuadernado en cartonè plastificado con lomo de tela, de $18 \times 24,5 \mathrm{~cm}$, compuesto de 408 páginas, 330 figuras y fotografias y 39 tablas. 